\title{
The Virtual Speculum in the New World Order ${ }^{1}$
}

\section{Donna J. Haraway}

\begin{abstract}
Beginning by reading a 1992 feminist appropriation of Michelangelo's Creation of Adam - in a cartoon in which the finger of a nude Adamic woman touches a computer keyboard, while the god-like VDT screen shows a disembodied fetus 'Virtual Speculum' argues for a broader conception of 'new reproductive technologies' in order to foreground justice and freedom projects for differently situated women in the New World Order. Broadly conceptualized reproductive practices must be central to social theory in general, and to technoscience studies in particular. Tying together the politics of self help and women's health movements in the United States in the 1970s with positions on reproductive freedom articulated within the Legal Defense and Educational Fund of the NAACP in the 1990s, the paper examines recent work in feminist science studies in several disciplinary and activist locations. Statistical analysis and ethnography emerge as critical feminist technologies for producing convincing representations of the reproduction of inequality. Untangling the semiotic and political-economic dialectics of invisibility and hypervisibility, 'Virtual Speculum' concludes by linking the well-surveyed amniotic fluid of on-screen fetuses and the off-frame diarrhea of uncounted and underfed infants in regimes of flexible accumulation and structural adjustment.
\end{abstract}

\section{Keywords}

feminism; reproduction; freedom projects; visual culture; ethnography; science studies; reproductive technologies; United States; Brazil

These are the days of miracle and wonder

This is the long distance call

The way the camera follows us in slo-mo

The way we look to us all

The way we look to a distant constellation

That's dying in a corner of the sky

These are the days of miracle and wonder

And don't cry, baby, don't cry

It was a dry wind

And it swept across the desert 
And it curled into the circle of birth

And the dead sand

Falling on the children

The mothers and the fathers

And the automatic earth

Medicine is magical and magical is art

The Boy in the Bubble

And the baby with the baboon heart

And I believe

These are the days of lasers in the jungle

Lasers in the jungle somewhere

Staccato signals of constant information

A loose affiliation of millionaires

And billionaires and baby

These are the days of miracle and wonder

This is the long-distance call

(C) 1986 Paul Simon/Paul Simon Music (BMI)

In its ability to embody the union of science and nature, the embryo might be described as a cyborg kinship entity.

Sarah Franklin (1993a: 131)

The fetus and the planet earth are sibling seed worlds in technoscience. If NASA photographs of the blue, cloud-swathed whole earth are icons for the emergence of global, national and local struggles over a recent natural-technical object of knowledge called the environment, then the ubiquitous images of glowing, free-floating, human fetuses condense and intensify struggles over an equally new and disruptive technoscientific object of knowledge, namely 'life itself' (Franklin, 1993b; Duden, 1993; Foucault, 1978). Life as a system to be managed - a field of operations constituted by scientists, artists, cartoonists, community activists, mothers, anthropologists, fathers, publishers, engineers, legislators, ethicists, industrialists, bankers, doctors, genetic counsellors, judges, insurers, priests, and all their relatives - has a very recent pedigree. The fetus and the whole earth concentrate the elixir of life as a complex system; that is, of life itself. Each image is about the origin of life in a postmodern world.

Both the whole earth and the fetus owe their existence as public objects to visualizing technologies. These technologies include computers, video cameras, satellites, sonography machines, optical fibre technology, television, micro cinematography and much more. The global fetus and the spherical whole earth both exist because of, and inside of, technoscientific visual culture. Yet, I think, both signify touch. Both provoke yearning for the physical sensuousness of a wet and blue-green earth and a soft, fleshy 
child. That is why these images are so ideologically powerful. They signify the immediately natural and embodied, over and against the constructed and disembodied. These latter qualities are charged against the supposedly violating, distancing, scopic eye of science and theory. The audiences who find the glowing fetal and terran spheres to be powerful signifiers of touch are themselves partially constituted as subjects in the material-semiotic process of viewing. The system of ideological oppositions between signifiers of touch and vision remains stubbornly essential to political and scientific debate in modern western culture. This system is a field of meanings that elaborates the ideological tension between body and machine, nature and culture, female and male, tropical and northern, coloured and white, traditional and modern, and lived experience and dominating objectification.

\section{The Sacred and the Comic}

Sometimes complicitous, sometimes exuberantly creative, western feminists have had little choice about operating in the charged field of oppositional meanings structured around vision and touch. Small wonder, then, that feminists in science studies are natural deconstructionists, who resolutely chart fields of meanings that unsettle these oppositions, these set ups that frame human and non-human technoscientific actors and sentence them to terminal ideological confinement (Treichler and Cartwright, 1992). Because the fruit issuing from such confinement is toxic, let us try to reconceive some of the key origin stories about human life that congeal around the images of the fetus. In many domains in contemporary European and US cultures, the fetus functions as a kind of metonym, seed crystal, or icon for configurations of person, family, nation, origin, choice, life and future. As the German historian of the body Barbara Duden put it, the fetus functions as a modern 'sacrum', i.e., as an object in which the transcendent appears. The fetus as sacrum is the repository of heterogeneous people's stories, hopes and imprecations. Attentive to the wavering opposition between the sacred versus the comic, the sacramental versus the vulgar, scientific illustration versus advertising, art versus pornography, the body of scientific truth versus the caricature of the popular joke, the power of medicine versus the insult of death, I want to proceed here by relocating the fetal sacrum onto its comic twin.

In this task, I am instructed by feminists who have studied in the school of the masters. Two feminist cartoons separated by twenty years, and a missing image that cannot be a joke, will concern me most in this essay's effort to read the comics in technoscience. Set in the context of struggles over the terms, agents and contents of human reproduction, all three of my 


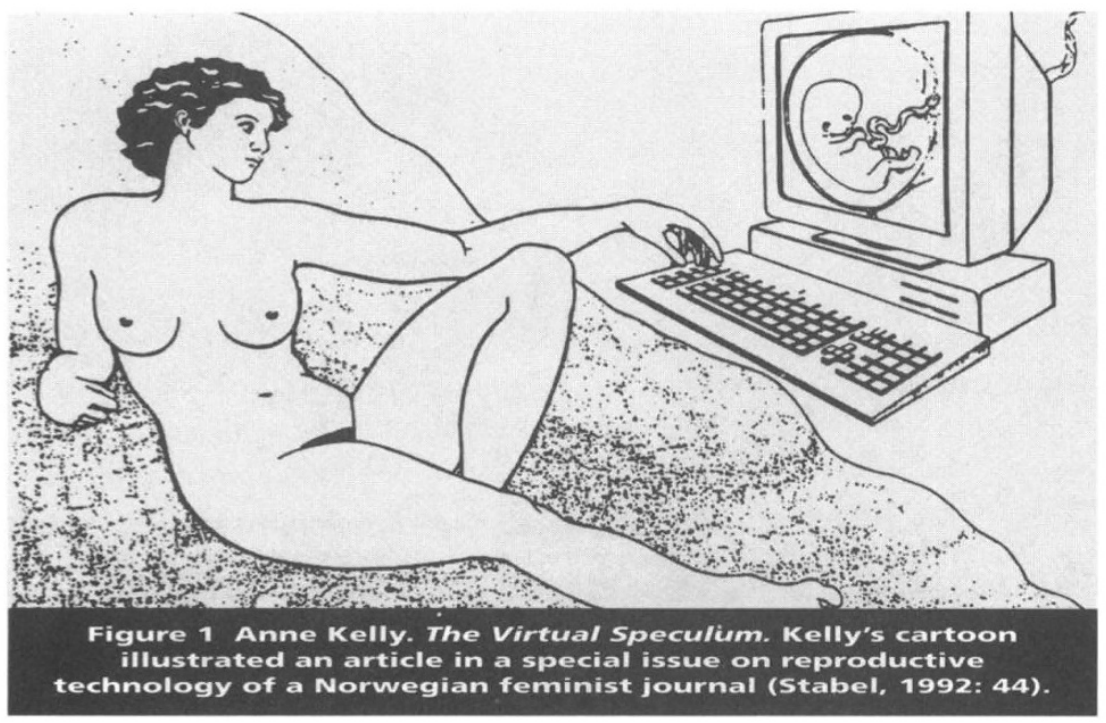

images trouble a reductionist sense of 'reproductive technologies'. Instead, the images are about a specifically feminist concept called 'reproductive freedom'. From the point of view of feminist science studies, freedom projects are what make technical projects make sense - with all the specificity, ambiguity, complexity and contradiction inherent in technoscience. Science projects are civics projects; they remake citizens. Technoscientific liberty is the goal (Flower, n.d.). Keep your eyes on the prize (Hampton 1986-87).

The first image, a cartoon by Anne Kelly that I have named the Virtual Speculum, is a representation of Michelangelo's painting of the Creation of Adam on the ceiling of the Sistine Chapel. The Virtual Speculum is a caricature in the potent political tradition of 'literal' reversals, which excavate the latent and implicit oppositions that made the original picture work. In Kelly's version, a female nude is in the position of Adam, whose hand is extended to the creative interface with, not God the Father, but a keyboard for a computer whose display screen shows the global digital fetus in its amniotic sac. A female Adam, the young nude woman is in the position of the first man. Kelly's figure is not Eve, who was made from Adam and in relation to his need. ${ }^{2}$ In the Virtual Speculum, the woman is in direct relation to the source of life itself.

The cartoon seems to resonate in an echo chamber with a Bell Telephone advertisement on US television in the early 1990 s, which urged potential long-distance customers 'to reach out and touch someone'. The racialethnic markings of the cast of characters varied in different versions of the ad. The visual text shows a pregnant woman, who is undergoing 


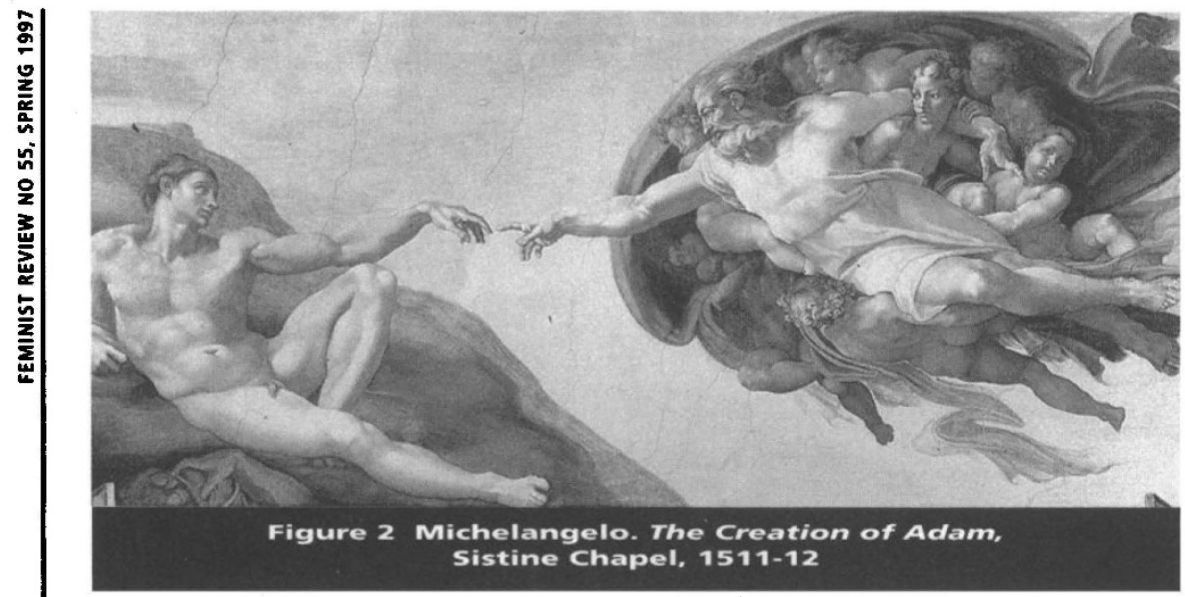

ultrasonographic visualization of her fetus, telephoning her husband, the father of the fetus, to describe for him the first spectral appearance of his issue. The description is performative; i.e., the object described comes into existence, experientially, for all the participants in the drama. Fathers, mothers and children are constituted as subjects and objects for each other and the television audience. Life itself becomes an object of experience, which can be shared and memorialized. Proving herself to be a literate citizen of technoscience, the pregnant woman interprets the moving gray, white and black blobs of the televised sonogram as a visually obvious, differentiated fetus. Family bonding is in full flower in Bell Telephone's garden of creation. Surrogate for the absent father, the mother touches the onscreen fetus, establishing a tactile link between both parents-to-be and child-to-be. Here are interactive television and video of a marvellous kind. The mother-to-be's voice on the phone and finger on the screen are literally the conduits for the eye of the father. These are the touch and the word that mediate life itself, that turn bodies and machines into eloquent witnesses and storytellers.

Through advertising, Bell Telephone puts us inside the dramatic scenarios of technology and entertainment, twins to biomedicine and art. In the ad, reproductive technology and the visual arts - historically bound to the specific kinds of observation practised in the gynaecological exam and the life-drawing class - come together through the circles of mimesis built into communications practices in the New World Order. Life copies art copies technology copies communication copies life itself. Television, sonography, computer video display and the telephone are all apparatuses for the production of the nuclear family on screen. Voice and touch are brought into life on screen. 
Kelly's cartoon works off of the fact, which remains odd to women of my menopausal generation, that in many contemporary technologically mediated pregnancies, expectant mothers emotionally bond with their fetuses through learning to see the developing child on screen during a sonogram (Rapp, forthcoming). And so do fathers, as well as members of Parliament and Congress (Hartouni, 1991; Franklin, 1993a). The sonogram is only one in a battery of visual artifacts that establish the fact of fetal life within political, personal and biomedical discourse. But obstetrical ultrasonography figures in powerful political-technical pedagogies for learning to see who exists in the world (Petchesky 1987). Selves and subjects are produced in such 'lived experiences'. Quickening, or the mother's testimony to the movement of the unseen child-to-be in her womb, has here neither the experiential nor epistemological authority it did, and does, under different historical modes of embodiment. In Kelly's version, the bonding produced by computer-mediated visualization also produces subjects and selves; the touch at the keyboard is generative - emotionally, materially and epistemologically. But things work both similarly and differently from the way they do on the Sistine Chapel ceiling or in the Bell Telephone TV advertisement.

In the Virtual Speculum the grayish blobs of the television sonogram have given place to the defined anatomical form of the free-floating fetus. Kelly's on-screen fetus is more like an in vivo movie, photograph or computergraphic reconstruction - all of which are received at least partly within the conventions of post-Renaissance visual realism, which the blob-like sonographic image has great difficulty invoking. The televised sonogram is more like a biological monster movie, which one still has to learn to view even in the late twentieth century. By contrast, to those who learned how to see after the revolution in painting initiated in the fifteenth and sixteenth centuries in Northern and Southern Europe, the free-floating, anatomically sharp, perspectivally registered fetal image appears self-evident at first viewing. Post-Renaissance anatomical realism and late twentieth-century computer-generated corporeal realism still share many, although not all, viewing conventions and epistemological assumptions.

The fetus like the one in Virtual Speculum is the iconic form that has been made so familiar by the exquisite, internationally distributed images produced by the Swedish biomedical photographer, Lennart Nilsson. Endoscopic intrauterine fetal visualization began in the 1950s, well before sonograms were part of the cultural terrain. The visible fetus became a public object with the April 1965 Life magazine cover featuring Nilsson's photograph of an intrauterine eighteen-week-old developing human being, encased in its bubble-like amniotic sac. The rest of the Nilsson photos in the 1965 Life story, 'The Drama of Life before Birth', were of extrauterine abortuses, beautifully lit and photographed in colour to become the 
visual embodiment of life at its origin. Not seen as abortuses, these gorgeous fetuses and their descendants signified life itself, in its transcendent essence and immanent embodiment. The visual image of the fetus is like the DNA double helix - not just a signifier of life, but also offered as the thing-in-itself. The visual fetus, like the gene, is a technoscientific sacrament. The sign becomes the thing itself in ordinary magico-secular transubstantiation.

Nilsson's images have spiked the visual landscape for the last thirty years, each time with announcements of originary art and technology, originary personal and scientific experience, and unique revelations bringing what was hidden into the light. Nilsson's photographs are simultaneously high art, scientific illustration, research tool and mass popular culture. The 1965 'Drama of Life before Birth' was followed by the popular coffee-table format book, A Child Is Born (Nilsson, 1977); the NOVA television special in 1983, 'The Miracle of Life'; the lavishly illustrated book (Nilsson, 1987) on the immune system, including images of developing fetuses, The Body Victorious; and the August 1990 Life cover photo of a seven-week-old fetus, with the caption, 'The First Pictures Ever of How Life Begins', and the accompanying story, 'The First Days of Creation' (Stabile, 1992). Finally, moving from conception through breast feeding, A Child Is Born was issued as a compact-disk adaptation, whose content-rich multimedia design offers interactive features as part of the visual fetal feast (Nilsson and Hamberger, 1994). A review for the disk in Wired, a prominent cyberculture magazine with about an 80 per cent male readership, assures the potential buyer, 'Interactivity remains an option, never an interruption or a chore' (Gasperini, 1994: 198). Truly, we are in the realm of miracles, beginnings and promises. A secular terrain has never been more explicitly sacred, embedded in the narratives of God's first Creation, which is repeated in miniature with each new life (Harding, 1990). Secular, scientific visual culture is in the immediate service of the narratives of Christian realism. We are in both an echo chamber and a house of mirrors, where, in word and image, ricocheting mimesis structures the emergence of subjects and objects. It does not seem too much to claim that the biomedical, public fetus - given flesh by the high technology of visualization - is a sacred-secular incarnation, the material realization of the promise of life itself. Here is the fusion of art, science and creation. No wonder we look.

The Kelly cartoon is practically an exact tracing of its original. Looking at Kelly's cartoon returns the reader of comics to Michelangelo's Creation of Adam. For 'modern' viewers, the entire ceiling of the Sistine Chapel signifies an eruption of salvation history into a newly powerful visual narrative medium. Accomplished between 1508 and 1512 under the patronage of Pope Julius II, the ceiling's frescos mark a technical milestone in mastering 
the Renaissance problem of producing a convincing pictorial rendering of narrative. The gestures and attitudes of the human body sing with stories. Part of the apparatus of production of Christian humanism, which has animated the history of western science, European early modern or Renaissance painting developed key techniques for the realization of man. Or, at least, that is a key way 'modern man' tells his history.

Although I will not trace them, innovations in literary technology are also part of this story. Eric Auerbach (1953) places the critical mutation in Dante's Divine Comedy, with its powerful figurations of salvation history that locate promised transcendental fulfillment in the material tissues of solid narrative flesh. Figurations are performative images that can be inhabited. Verbal or visual, figurations are condensed maps of whole worlds. In art, literature and science, my subject is the technology that turns body into story, and vice versa, producing both what can count as real and the witnesses to that reality. In my own mimetic critical method, I am tracing some of the circulations of Christian realism in the flesh of technoscience. I work to avoid the terms 'Judeo-Christian' or 'monotheist' because the dominant technoscientific visual and narrative materials here are specifically secular Christian renditions of partially shared Jewish, Muslim and Christian origin stories for science, self and world. But I am also trying to trace the story within a story, within which we learn to believe that fundamental revolutions take place. I am trying to retell some of the conditions of possibility of the stories technoscientific humans continue to tell ourselves. It is doubtful that historical configurations conventionally called the 'Renaissance', or in a later version of the birth of the modern, the 'Scientific Revolution', or today's rendition called the 'New World Order' actually have been unique, transformative theatres of origin. But they have been narrativized and canonized as such cradles of modern humanity, especially technoscientific humanity with its secular salvation and damnation histories. Certainly, if only by opposition, I am complicit in the narrativization and figuration of the Scientific Revolution and the New World Order.

Metonymic for the entire array of Renaissance visual techniques, Albrecht Dürer's Draughtsman Drawing a Nude (1538) conventionally dramatizes the story of a revolutionary apparatus for turning disorderly bodies into disciplined art and science. In the drawing, an old man uses a line-of-sight device and a screen-grid to transfer point-for-point the features of a voluptuous, reclining female nude onto a paper grid marked off into squares. The upright screen-grid separates the prone woman on the table, whose hand is poised over her genitals, from the erectly seated draughtsman, whose hand guides his stylus on the paper. Dürer's engraving attests to the power of the technology of perspective to discipline vision to produce a 


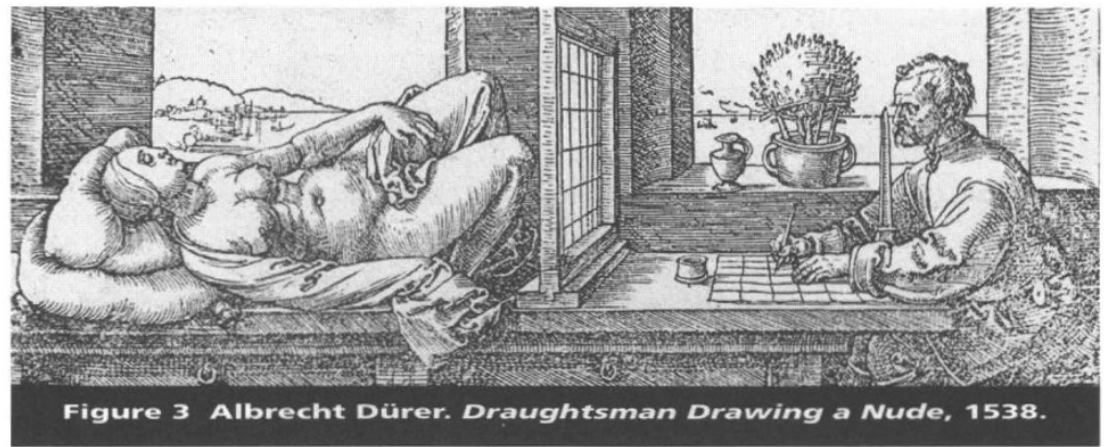

new kind of knowledge of form. As art historian Lynda Nead argued, ' $[\mathrm{V}]$ isual perception is placed on the side of art and in opposition to the information yielded through tactile perception. ... Through visual perception we may achieve the illusion of a coherent and unified self' (Nead, 1992: 28). Here also, with Dürer, the disciplining screen between art and pornography is paradigmatically erected.

The gendering of this kind of vision is, of course, not subtle. Indeed, feminists argue that this visual technology was part of the apparatus for the production of modern gender, with its proliferating series of sexually charged oppositions condensed into the tension at the interface between touch and vision. Nead writes, 'Woman offers herself to the controlling discipline of illusionistic art. With her bent legs closest to the screen, [Dürer's] image recalls not simply the life class but also the gynaecological examination. Art and medicine are both foregrounded here, the two discourses in which the female body is most subjected to scrutiny and assessed according to historically specific norms' (1992: 11). Obviously, it is only after the institutions of the life class and the gynaecological exam emerged that Dürer's print can be retrospectively read to recall them. As part of reforming her own self-making technology, Nead, the feminist art historian, is telling a story about the birth of the figure of Woman. As for me, the feminist analyst of technoscience attuned to artistic and biomedical visual delights, I see Dürer's majestic print and Bell Telephone's television advertising through the grid of Kelly's virtual speculum. In the life class and gynaecological exam that is technoscience, critique caresses comedy. I laugh; therefore, I am . . . implicated. I laugh; therefore, I am responsible and accountable. That is the best I can do for moral foundations at the tectonic fault line joining the sacred, the scientific and the comic. And everyone knows that end-of-the-millennium Californians build their houses, and their theories, on fault lines. 
In Renaissance visual technology, form and narrative implode; and both seem merely to reveal what was already there, waiting for unveiling or discovery. This epistemology underlies the European-indebted sense of what counts as reality in the culture, believed by many of its practitioners to transcend all culture, called modern science. Reality, as westerners have known it in story and image for several hundred years, is an effect, but cannot be recognized as such without great moral and epistemological angst. The conjoined western modern sense of the 'real' and the 'natural' was achieved by a set of fundamental innovations in visual technology beginning in the Renaissance. ${ }^{3}$

Twentieth-century scientists call on this earlier visual technology for insisting on a specific kind of reality, which readily makes today's observers forget the conditions, apparatuses and histories of its production. Especially in computer and information sciences and in biotechnology and biomedicine, representations of late twentieth-century technosciences make liberal use of iconic exemplars of early modern European art/humanism/technology. Current images of technoscience quote, point to, and otherwise evoke a small, conventional, potent stock of Renaissance visual analogues, which provide a legitimate lineage and origin story for technical revolutions at the end of the Second Christian Millennium. Today's Renaissance Sharper Image Catalogue includes the anatomized human figures in De bumanis corporis fabrica of Andreas Vesalius, published in Basel in 1543; Leonardo da Vinci's drawing of the human figure illustrating proportions, or the 'Vitruvian Man' (c. 1485-90); Dürer's series of plates on perspective techniques; the maps of the cartographers of the 'Age of Discovery'; and, of course, Michelangelo's Creation of Adam. Invoking this ready stock, a venture capitalist from Kleiner Perkins Caufield \& Byers mutated the analogies to make a related historical observation, noting that biotech has been 'for human biology what the Italian Renaissance was for art' (Hamilton 1994: 85). In technoscientific culture, at the risk of mild overstatement, I think one can hardly extend an index finger (or finger substitute) toward another hand (or hand substitute) without evoking the First Author's gesture (or First Author Substitute's gesture).

In Michelangelo's version of authorship, Adam lies on the earth; and, conveyed by angels, God moves toward him from the heavens. An elderly, patriarchal God the Father reaches his right index finger to touch the languidly extended, left index finger of an almost liquid, nude, young-man Adam. A conventional art history text concludes, 'Adam, lying like a youthful river god, awakens into life' (Hays, 1967: 99; see also Jansen and Jansen 1963: 359-60). Adam is a kind of watery, earth-borne fetus of humanity, sparked into life on a new land by the heavenly Father. 
Michelangelo's God, however, is also carrying another, truly unborn human being. Still in the ethereal regions above earth, Eve is held in the shelter of God's left arm; and at the origin of mankind she and Adam are looking toward each other. It is not entirely clear who Adam sees, God or Woman - exactly the problem addressed by the screen barrier between art and pornography. Maybe in innocence before the Fall and at the moment of the renaissance of modern vision, a yearning Adam can still see both at once. Touch and vision are not yet split. Adam's eye caresses both his Author and his unborn bride.

Anne Kelly's drawing suggests other screens as well, such as that between art and science, on the one hand, and caricature and politics, on the other. Like the transparent film between art and pornography, the interface between the medico-scientific image and the political cartoon unstably both joins and separates modest witnesses and contaminated spectators. In both potent zones of transformation, the reclining female nude seems suggestively common. Dürer's woman in Draughtsman Drawing a Nude, the Venus d'Urbino by Titian (1487?-1576), the Rokeby Venus by Diego Velázquez (1599-1660), Venus at Her Toilet by Peter Paul Rubens (1577-1640), and Edouard Manet's Olympia (1863) are all ancestors for Kelly's first woman. Kelly's cartoon figure depends on the conventions for drawing the recumbent nude female in modern western painting. Dürer's, Titian's, Velázquez's, Rubens' and Manet's nudes all figure prominently in accounts of the emergence of modern ways of seeing (Clark 1985). The relation between Manet's African serving woman and the reclining European nude also figures in the fraught racialized visual history of modern Woman (Nead, 1992: 34-46; Harvey, 1989: 54-56). Clearly, the Virtual Speculum keeps its eyes on the prize.

Lynn Randolph's painting, Venus, part of her Ilusas or 'deluded women' series, is a more formal feminist intervention into the conventions of the female nude and her associated secretions and tools. Scrutinizing the standard line between pornography and art, Randolph (1993: 1) writes:

This contemporary Venus is not a Goddess in the classical sense of a contained figure. She is an unruly woman, actively making a spectacle of herself. Queering Botticelli, leaking, projecting, shooting, secreting milk, transgressing the boundaries of her body. Hundreds of years have passed and we are still engaged in a struggle for the interpretive power over our bodies in a society where they are marked as a battleground by the church and the state in legal and medical skirmishes.

Kelly, however, is drawing a female Adam, not a Venus. The story is different, and so is the optical technology. Kelly's woman looks not into the 


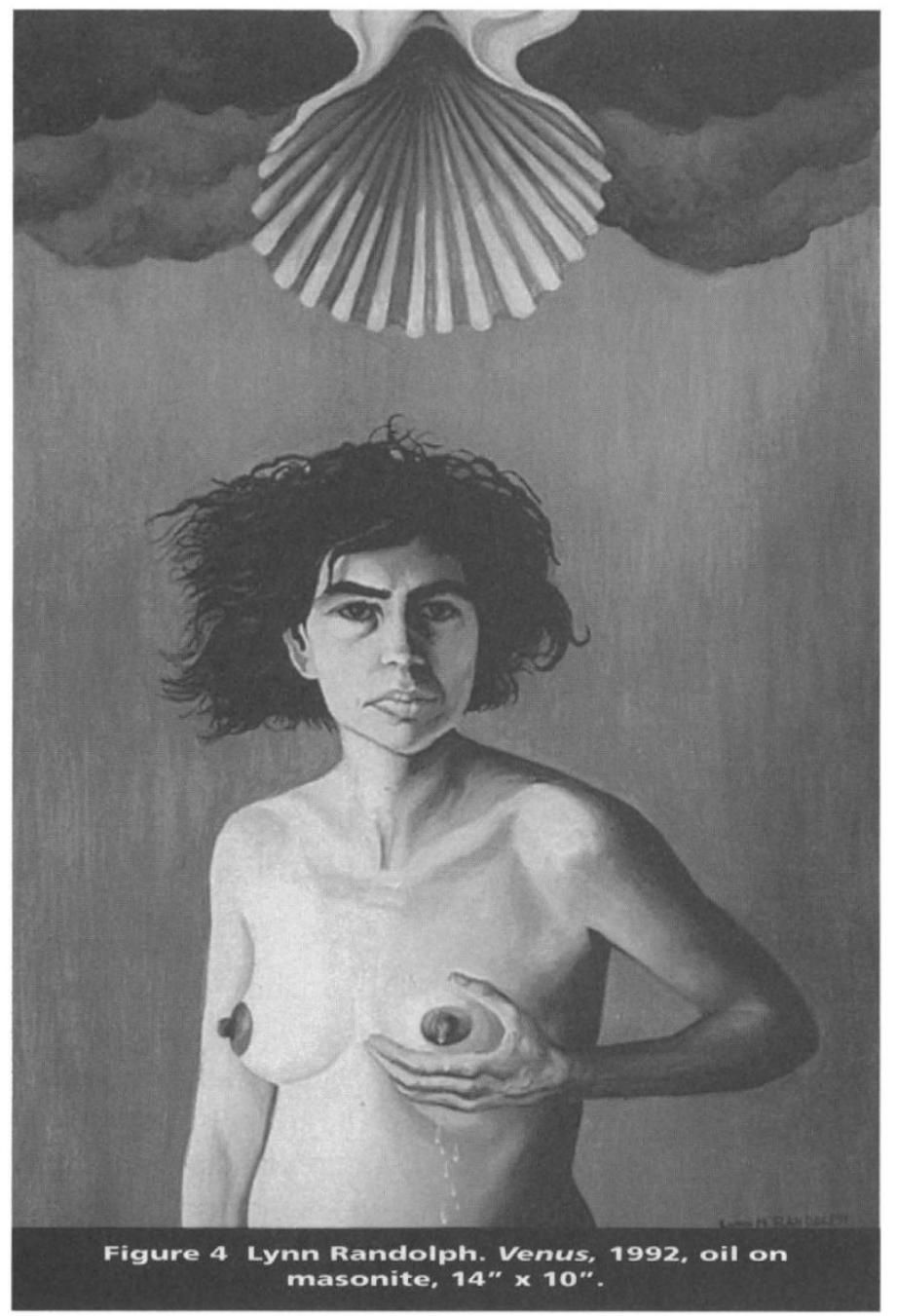

is in the heavenly position of Michelangelo's God. The 'venereal' women with mirrors in the history of western painting have given way in Kelly to the 'authorial' woman with keyboard and computer terminal. Kelly's woman is not in a story of reflections and representations. Whatever she sees, it is not her reflection. The computer screen is not a mirror; the fetus is not her double or her copy. First woman in Virtual Speculum looks not into the normal reality established by Renaissance perspective, but into the virtual reality given by a time called postmodernity. Both realities are technical effects of particular apparatuses of visual culture. Both realities are simultaneously material, embodied and imaginary. Both realities can only be inhabited by subjects who learn how to see and touch with the right 
conventions. It's all a question of interactive visual technology. Reach out and touch someone; this is the long distance call.

Not under the arm of God, but in computer-generated visual space, the fetus meets first woman's gaze. Kelly's unborn fetus, not the Adam-like woman, is in the position of Michelangelo's still-uncreated Eve. From the non-perspective of virtual space, the first woman and the fetus confront each other, as Adam and Eve did in Michelangelo's version of human creation. In that reading, the computer screen is the embracing arm of God. Has His gender value been transmuted as Adam's has been? Is the computer womb now female, or is gender one of the many things at stake? Kelly's cartoon allows at least two readings of the fetus: it is either in the position of God or in that of the not-yet-created Eve. If the fetus is Eve, the computer itself, with keyboard, is the encompassing deity reaching out to the female Adam's extended but limp hand. That reading makes Kelly's Adam the effect of the computer, the effect of the 'creative' technologies of cyberspace. On the other hand, the female Adam has her hand on the keypad; she seems to be in the position of author. Then, the fetus is her file, which she is writing, editing or, as one viewer suggested, deleting. Certainly, the politics of abortion are implicitly in this cartoon. Maybe she is reaching for the 'escape' key, or perhaps merely the 'control' key.

Like traditional masculine figures in the reproductive imagery of technoscience, who have brain children all the time, Kelly's first woman seems to have a pregnancy associated with the organs of cognition and writing. Her pregnancy is literally extra-uterine. Or, perhaps Kelly's Adam is not pregnant at all; she may be viewing a fetus with no further connection to her once the file is closed. Literally, the fetus is somehow 'in' the computer. This fetus is a kind of data structure, whose likely fate seems more connected to downloading than birth or abortion. Just as the computer as womb-brain signifies the superior creativity of artificial intelligence (AI), the on-screen fetus is an artificial life (ALife) form. As such, Virtual Speculum's fetus is not disembodied. Rather, the specific form of embodiment inside the apparatuses of technoscience is the material conundrum presented by the cartoon. The computer is metonymic for technoscience, an inescapable materialization of the world. Life itself, a kind of technoscientific deity, may be what is virtually pregnant. These ontologically confusing bodies, and the practices that produce specific embodiment, are what we have to address, not the false problem of disembodiment. Whose and which bodies - human and non-human, silicon-based and carbonbased - are at stake and how, in our technoscientific dramas of origin? And what is the specific political and moral accountability attached to these notalways-human bodies? 
The proliferating readings of Kelly's cartoon make one conclusion inescapable: reversals and substitutions never just substitute for or reverse the values of the original. Rather, reversals and substitutions undo the original, opening the story up in unexpected ways. Themselves forms of repetition, reversals and substitutions make the condition of all repetition obvious. The great stories of mimesis are undone. Caricature breaks the unspoken agreements that stabilized the original. Caricatures break the frame of salvation history. Perhaps that point gives the key for reading the multiple out-of-frame elements of Kelly's cartoon. The pregnancy is ectopic, to say the least; the fetal umbilical cord and barely visible placenta go off screen on the display terminal; and the electrical cords wander up and off screen from the whole cartoon, with no point of attachment in view. The computer terminal, itself a work station, seems to be the metafetus in the picture. Further, this meta-fetus is an extrauterine abortus, with ripped out umbilical cords like those in Lennart Nilsson's emblematic photographs of the beginnings of life itself. There is an odd kind of obstetrical art and technology at work here. It is not just Dürer's visual technology that makes a feminist 'recall' the gynecological exam and the life class, those troubling and productive scenes of medical science and of art. In Kelly's meditation, the examination of both art and life is distinctly eccentric.

\section{Fetal Work Stations and Feminist Technoscience Studies}

If Kelly's fetus cannot be the woman's reflection, the unborn being might be her project, or someone's project. More likely, the fetus in cyberspace signifies an entity that is constituted by many variously related communities of practice. This fetus is certainly an object of attention and a locus of work (Casper, 1995b), and Kelly's First Woman is at her workstation. Feminist scholars have also been at a 'fetal workstation'. Like data processors at their video terminals in the information economy, feminists' positions at their analytical keyboards have not always been a matter of choice. Reproduction has been at the centre of scientific, technological, political, personal religious, gender, familial, class, race and national webs of contestation for at least the last twenty-five years. Like it or not, as if we were children dealing with adults' hidden secrets, feminists could not avoid relentlessly asking where babies come from. Our answers have repeatedly challenged the reduction of that original and originating question to literalized and universalized women's body parts. It turns out that addressing the question of where babies come from puts us at the centre of the action in the New World Order. With roots in local and international women's health movements as well as in various scholarly communities, since the early 1970 s feminists have developed a rich toolkit for technoscience studies through their 
attention to the social-technical webs that constitute reproductive practice (Ginsberg and Rapp, 1991, 1995). Idiosyncratically, I will inspect a small, recent inventory from this toolbox in order to pursue my inquiry into the optical properties of the virtual speculum.

In their powerful paper on the many constituencies who construct the French abortifacent called RU486, sociologist Adele Clarke and her former student Teresa Montini developed social worlds and arena analysis for feminist science studies. Clarke and Montini (1993) identify reproductive and other scientific-medical specialists; pharmaceutical companies; antiabortion groups; feminist pro-choice groups; women's health movement groups; politicians, Congress, and the Food and Drug Administration; and women users and consumers of RU486. The authors are clear that their own analysis turns the volume up or down on some actors more than others; their own representations are part of the struggle for what will count as reproductive freedom, and for whom. Attention to this kind of point characterizes feminist science studies in general, whether generated from the academy or policy-forming and community-action sites.

Using these tools, Monica Casper (1995a and b) studies human fetal surgery historically and ethnographically. Casper is developing the notions of the 'technofetus' and the 'fetus as work object'. Casper's approach shows the fetus to be the site and result of multiple actors' work practices, including the mother's. Because Casper is necessarily a member of interdigitating communities of scholarly and political practice, her own positioning is neither invisible nor unaccountable. The many communities of practice who are held together around the technofetus are by no means necessarily in harmony. Their work tools - rhetorical and material - can make the fetus into very different kinds of entities. However, neither 'multiplicity' nor 'contestation' for their own sake are the point in feminist science studies. Joining analysts to subjects and objects of analysis, questions of power, resources, skills, suffering, hopes, meanings and lives are always at stake.

In a similar spirit, Charis Cussins (1996), trained in a science studies programme, traces the continual 'ontological choreography' that constructs subjects, objects and agents at an infertility clinic. Subjects and objects are made and unmade in many ways in the extended processes of infertility treatment. Cussins shows that the different stakes, temporalities, trajectories and connections and disconnections to women's and others' bodies and part-bodies - as humans and non-humans are enrolled together in the practices of technoscience - require ethnographic, sustained inquiry.

Anthropologist Rayna Rapp's multi-year ethnographic study of women in 
and racially marked groups also vividly describes the plethora of materialsemiotic worlds in which fetuses and pregnant women have their being (Rapp, 1994 and forthcoming). Women who accept and who refuse the procedures of fetal genetic diagnosis, research geneticists, genetic counsellors, family members, support groups for people with genetically disabled children - all these people, variously intertwined with machines, babies, fetuses, clinical materials and with each other, make up Rapp's research community. The consequences of all the actors' locations in these dynamic, differentiated worlds are crucial to her account; and her own profound mutations in the course of doing the work grow from and feed back into the research and writing.

In the linked interdisciplinary worlds of feminist accounts of technoscience, Valerie Hartouni (1996), located professionally in a communications department, takes up the many contending discourses of maternal nature in contemporary reproductive cultures in the US. In a subtle and incisive series of essays, Hartouni examines how class, gender and genetic parenthood interdigitate in the Baby $M$ surrogate mother legal arguments; how the judicial injunction not to speak of race in the case of the AfricanAmerican gestational surrogate Anna Johnson, who carried a child for a mixed-race (Filipina-Anglo) couple, was nonetheless part of the saturation of the case with racial and class markings; and how the performance video, S'Aline's Abortion, despite explicit pro-choice intentions, nonetheless was positioned by its visual rhetoric inside anti-choice narratives for many audiences. Hartouni's work is part of the broad feminist inquiry into how the genetic relationship displaces other discourses of connection to a child in legal, biotechnical, familial and entertainment worlds. Her writing contributes to the project of crafting feminist visual literacy needed for working effectively inside a reproductive technoscience politics saturated with visual communications practices.

Reproductive politics are at the heart of questions about citizenship, liberty, family and nation. Feminist questions are not a 'special preserve', but a 'general' discourse critical for science studies as such. Inaugural acts of chief executive officers in mid-1990s US politics illustrate an aspect of this claim. After taking the oath of office as President of the United States in January 1993, Bill Clinton issued his first executive orders, which established his presidency symbolically and materially. His first acts did not concern war or other conventional domains of national interest and manly action. His first acts had to do with embryos and fetuses embedded in technoscientific contestations. Through embryos and fetuses, those orders had to do with entire forms of life - public, embodied and personal - for the citizens of the state. Clinton began the process of lifting restrictions on providing information about abortion in federally funded clinics, 
permitting medical experimentation on aborted fetal tissue and allowing the importation of the controversial abortifacent and potential cancer treatment, RU486.

Similarly, but with opposite political intent, the first official act of Pete Wilson after he was re-elected Governor of California in 1994 was to order a state programme closed that provided pre-natal care to pregnant 'undocumented' immigrant women. Wilson had staked his campaign on Proposition 187, which denied so-called illegal immigrants virtually all social services, especially public education and non-emergency medical care. Despite the denials of its backers, Proposition 187 was widely understood to have fundamental racial-ethnic, class and national targets, especially working-class Latinos of colour coming across the Mexican-US border. The measure passed by a two-to-one margin. That is, Proposition 187 was overwhelmingly popular with the older, Republican, white and economically affluent electorate who voted in the 1994 election - many of whom, including a candidate for US Senate who supported Proposition 187, had recently hired 'illegal' women of colour to care for their white children, while seeking to withhold social services from the children of these same employees. To withhold reproductive health care from 'undocumented' women of colour, whose children would be born US citizens if their pregnancies came to term in California, was the first concern of the re-elected executive. Fetal protection (and the health of women) suddenly looked like a bad idea, and fetal endangerment (and the endangerment of 'illegal' women of colour) was the direct implication of the governor's inaugural act. Biomedicine - where post-natal people, machines, fetuses, health beliefs, diagnostic procedures and bodily fluids are enrolled together into potent configurations - was the arena of conflict. Biomedicine is where freedom, justice and citizenship were at stake.

Finally, Clinton's first public acts as commander-in-chief threatened to queer the sacred site of the citizen-warrior by changing the US armed forces' policy of excluding acknowledged gay men and lesbians from the military. The citizen-soldier's 'manliness' has long been at the centre of the political theory of the state and citizenship. However inadequately, colour and gender were addressed in the US military before the category of queer. The tragicomic panic that ensued in Congress and among the Joint Chiefs of Staff thwarted Clinton's intent to deal with the matter by executive order. My point is that discursive, embodied entities like the fetus, the pregnant immigrant and the homosexual are not the subjects of 'social' issues, in contrast to 'political' matters of state and public policy. Like the embryo or fetus and the 'undocumented' pregnant woman, the queer is at the heart of contests to reconfigure precisely what public space is and who inhabits it. Technoscience is intrinsic to all of these struggles. 
The work sketched here shows that to study technoscience requires an immersion in worldly material-semiotic practices, where the analysts, as well as the humans and non-humans studied, are all at risk - morally, politically, technically and epistemologically. Science studies that do not take on that kind of situated knowledge practice stand a good chance of floating off screen into an empyrean and academic never-never land. 'Ethnography', in this extended sense, is not so much a specific procedure in anthropology, as it is a method of being at risk in the face of the practices and discourses into which one inquires. To be at risk is not the same thing as identifying with the subjects of study; quite the contrary. And selfidentity is as much at risk as the temptation to identification. One is at risk in the face of serious non-identity that challenges previous stabilities, convictions or ways of being of many kinds. An 'ethnographic attitude' can be adopted within any kind of inquiry, including textual analysis. Not limited to a specific discipline, an ethnographic attitude is a mode of practical and theoretical attention, a way of remaining mindful and accountable. Such a method is not about 'taking sides' in a pre-determined way, but neither are moral and political commitments hygienically expunged. Ethnography as I understand the practice is about risks, purposes, meanings and hopes - one's own and others' - embedded in knowledge projects, including technoscientific ones (Downey and Dumit, forthcoming; Escobar, 1994).

Ethnography is not only a mode of attention, however. Textual analysis must articulate with many kinds of sustained scholarly interaction among living people in living situations, historical and contemporary, documentary and in vivo. These different studies need each other, and they are all theory-building projects. No one person does all the kinds of work; feminist science studies is a collective undertaking that cultivates a practice of learning to be at risk in all the sorts of work necessary to an account of technoscience and medicine.

Under these conditions, looking for a feminist doctrine on reproductive technology, in particular, or on technoscience, in general, would be ludicrous. But understanding feminist technoscience scholarship as a contentious search for what accountability to freedom projects for women might mean, and how such meanings are crafted and sustained in a polyglot world of men and women, is not ludicrous. Pre-set certainties, feminist and otherwise, about what is happening in theatres of reproduction, or any theatre of technoscience, stand an excellent chance of being flagrantly wrong. But feminist questions shape vision-generating technologies for science studies. Freedom and justice questions are intrinsic to the inquiry about the joinings of humans and non-humans. Feminist technoscience inquiry is a speculum, a surgical instrument, a tool for widening the 
openings into all kinds of orifices to improve observation and intervention in the interest of projects that are simultaneously about freedom, justice and knowledge. In these terms, feminist inquiry is no more innocent, no more free of the inevitable wounding that all questioning brings, than any other knowledge project.

It does not matter much to the figure of the still-gestating, feminist, antiracist, mutated modest witness whether freedom, justice and knowledge are branded as modernist or not; that is not our issue. We have never been modern (Latour, 1993; Haraway, 1994). Rather, freedom, justice and knowledge are - in bell hooks' terms - about 'yearning', not about putative Enlightenment foundations. Keep your eyes on the prize. Keep our eyes on the prize. For hooks, yearning is an affective and political sensibility allowing cross-category ties that 'would promote the recognition of common commitments and serve as a base for solidarity and coalition' (hooks, 1990: 27; see also Braidotti, 1994: 1-8; and Sandoval, forthcoming). Yearning must also be seen as a cognitive sensibility. Without doubt, such yearning is rooted in a reconfigured unconscious, in mutated desire, in the practice of love, in the ecstatic hope for the corporeal and imaginary materialization of the antiracist female subject of feminism. And all other possible subjects of feminism. Finally, freedom, justice and knowledge are not necessarily nice and definitely not easy. Neither vision nor touch is painless, on or off screen.

\section{The Right Speculum for the Job ${ }^{4}$}

An inquiry into instruments of visualization, Kelly's cartoon can carry us another step toward understanding feminist science studies. Virtual Speculum is replete with signifiers of 'choice', a term that has been encrusted by colonies of semiotic barnacles in the reproductive politics of the last quarter century. What counts as choice, for whom, and at what cost? What is the relation of 'choice' to 'life', and especially to 'life itself'?

Kelly's cartoon is not denunciatory. I do not see in it any stereotyped position on new reproductive technologies or pious certainty about supposed alienation and disembodiment. Nor is Kelly's cartoon celebratory. It does not reflect credit on the original; it does not announce a new scientific age in the image of an original Creation. The cartoon depends on signifiers of information and communications technologies. Information is a technical term for signal-to-noise discrimination; information is a statistical affair for dealing with differences. Information is not embedded in a metaphysics of reflection and representation. The pixel grid of the cartoon's screen will not yield a point-for-point emplotment of an original body, disciplined through an ontology and epistemology of mimesis, reflection and representation. Kelly is not Dürer. 
Instead, Virtual Speculum is diffractive and interrogatory: It asks, 'Is this what feminists mean by choice, agency, life and creativity? What is at stake here, and for whom? Who and what are the human and non-human centres of action? Whose story is this? Who cares?' The view screen records interfering and shifted - diffracted - patterns of signifiers and bodies. What displacements in reproductive positioning matter to whom and why? What are the conditions of effective reproductive freedom? Why are public and personal narratives of self-creation linked to those of pregnancy? Whose stories are these? Who is in the cartoon, who is missing, and so what? What does it mean to have the public fetus on screen? Whose fetuses merit such extraordinary attention? What does it mean to embed a joke about selfcreation and pregnancy inside western and 'white' conventions for painting the female nude? Kelly's cartoon is embedded inside signifiers of the Creation, Renaissance, Scientific Revolution, Information Age and New World Order. How does salvation history get replicated or displaced inside technoscience? What are the consequences of the overwhelmingly Christian signifiers of technoscience? If Michel Foucault wrote about the care of the self and the development of disciplinary knowledge in two different cultural configurations within western history, Kelly is sketching an inquiry into the apotheosis of the fetus and reproductive technoscience as a diagnostic sign of the end of the Second Christian Millennium. How is care of the fetus today analogous to care of the self in classical antiquity - an elite set of practices for producing certain kinds of subjects?

What is the right speculum for the job of opening up observation into the orifices of the technoscientific body politic to address these kinds of questions about knowledge projects? I want to approach that question by going back to the eruption of the gynaecological speculum as a symbol in US feminist politics in the early 1970 s. Many feminists of my cohorts - largely young, white, middle-class women - 'seized the masters' tools' in the context of the Women's Liberation Movement and its activist women's health movement (Lorde, 1984). Armed with a gynaecological speculum, a mirror, a flashlight and - most of all - each other in a consciousnessraising group, women ritually opened their bodies to their own literal view. The speculum had become the symbol of the displacement of the female midwife by the specialist male physician and gynaecologist. The mirror was the symbol forced on women as a signifier of our own bodies as spectaclefor-another in the guise of our own supposed narcissism. Vision itself seemed to be the empowering act of conquerors.

More than a little amnesiac about how colonial travel narratives work, we peered inside our vaginas toward the distant cervix and said something like, 'Land ho! We have discovered ourselves and claim the new territory for women.' In the context of the history of western sexual politics - that 
is, in the context of the whole orthodox history of western philosophy and technology - visually self-possessed sexual and generative organs made potent tropes for the reclaimed feminist self. We thought we had our eyes on the prize. I am caricaturing, of course, but with a purpose. 'Our Bodies, Ourselves' was both a popular slogan and the title of a landmark publication in women's health movements. ${ }^{5}$

The repossessed speculum, sign of the Women's Liberation Movement's attention to material instruments in science and technology, was understood to be a self-defining technology. Those collective sessions with the speculum and mirror were not only symbols, however. They were self-help and self-experimentation practices in a period in which abortion was still illegal and unsafe. The self-help groups developed techniques of menstrual extraction, i.e., early abortion, that could be practised by women alone or with each other outside professional medical control. A little flexible tubing joined the mirror and the speculum in more than a few of those sessions. Meanwhile, biomedical clinicians were introducing the sonogram and endoscopic fetal visualization, while Lennart Nilsson's photographs spread around the medicalized globe. We had to wonder early if we had seized the right tools.

Still, the sense of empowerment experienced by the women in early 1970 s self-help groups was bracing. The spirit was captured in a cartoon in the July 1973 issue of Sister, the Newspaper of the Los Angeles Women's Center. Wonder Woman - the Amazonian princess from Paradise Isle, complete with her steel bracelets that could deter bullets; stiletto high heels; low-cut, eaglecrested bodice; star-spangled, blue mini-shorts; and her magic lasso for capturing evil doers and other transportation needs - seizes the radiant speculum from the white-coat-clad, stethoscope-wearing, but cowering white doctor and announces, 'With my speculum, I am strong! I can fight!'

Wonder Woman entered the world in 1941 in Charles Moulton's popular cartoon strips. Moulton was William Moulton Marston, psychologist, attorney, inventor of the lie-detector test, prison reformer and businessman. Marston's conventional feminism ascribed force bound by love to women and opposed that to men's attraction to force alone. Despite her origins in the Amazon, Wonder Woman's ethnicity was unmistakably white. Her expletives ('Merciful Minerva!' and 'Great Hera!') and her other cultural accoutrements locate her firmly in the modern myth of western origins in ancient Greece, relocated to the New World. She could have easily joined a US white sorority in the 1940s and 1950s, with their Greek-revivalist themes and rituals. The guiding goddesses of Wonder Woman's Amazonian matriarchal paradise were Aphrodite and Athena (Edgar, 1972). 


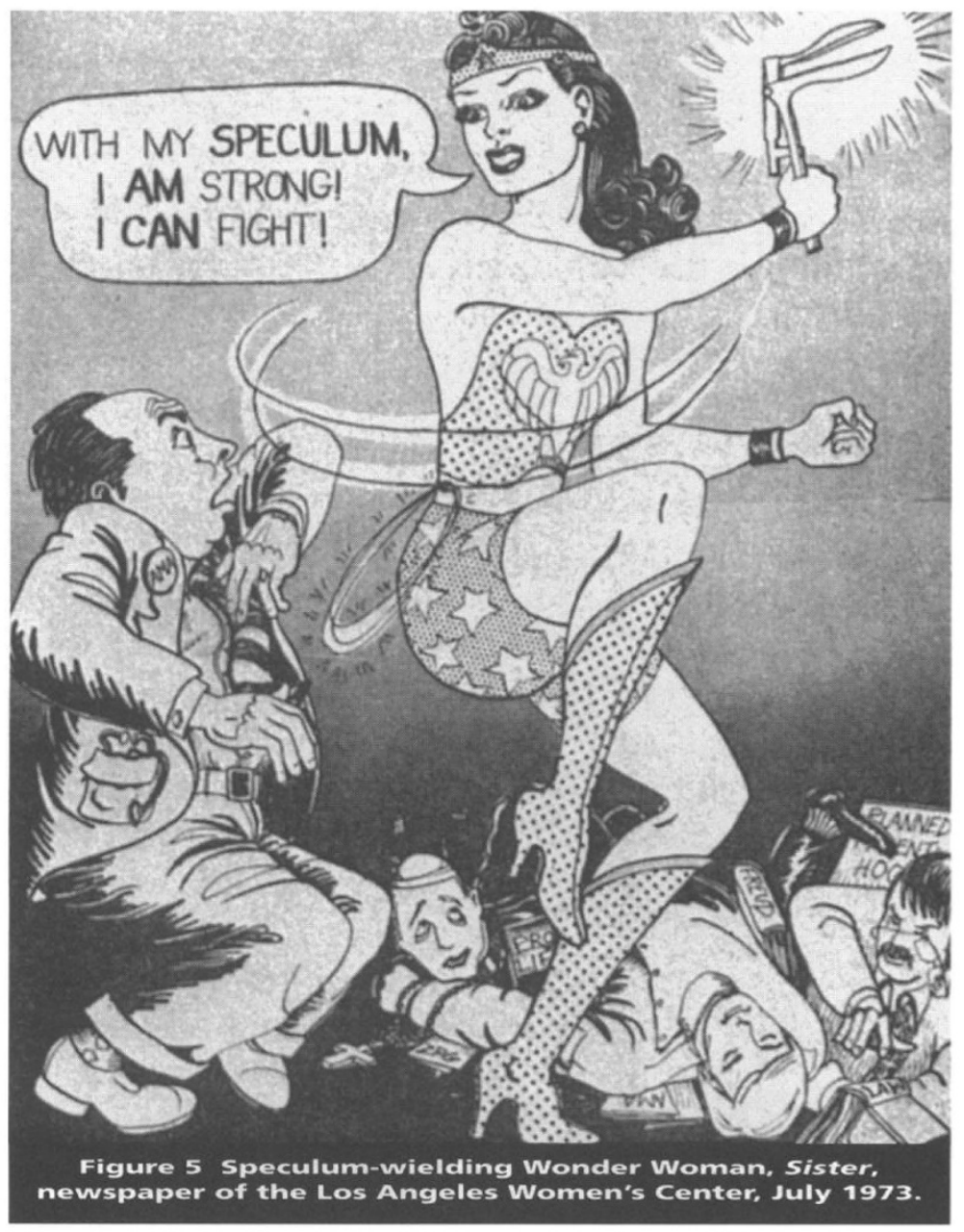

After falling into a sad state by the end of the 1960 s, Wonder Woman was resurrected in several venues in the early 1970s. Wonder Woman's first female comic-book editor, Dorothy Woolfolk, brought her back to the mass market in 1973. Ms. magazine put Wonder Woman on the cover of its first issue in July 1972, under the slogan, 'Wonder Woman for President'. The Vietnam War was raging on one side of the cover, and a 'Peace and Justice in '72' billboard adorned the store-fronts on a US street on the other side. A gigantic Wonder Woman was grabbing a US fighter jet out of the sky with one hand and carrying an enlightened city in her magic lasso in the other hand. The city might be a feminist prototype for the massmarket, computer-simulation game of the $1990 \mathrm{~s}$, SimCity $2000^{\mathrm{TM}}$ (Bleecker, 1995). Wonder Woman's lasso outlined a glowing urban tetrahedron that would have made Buckminster Fuller proud. 


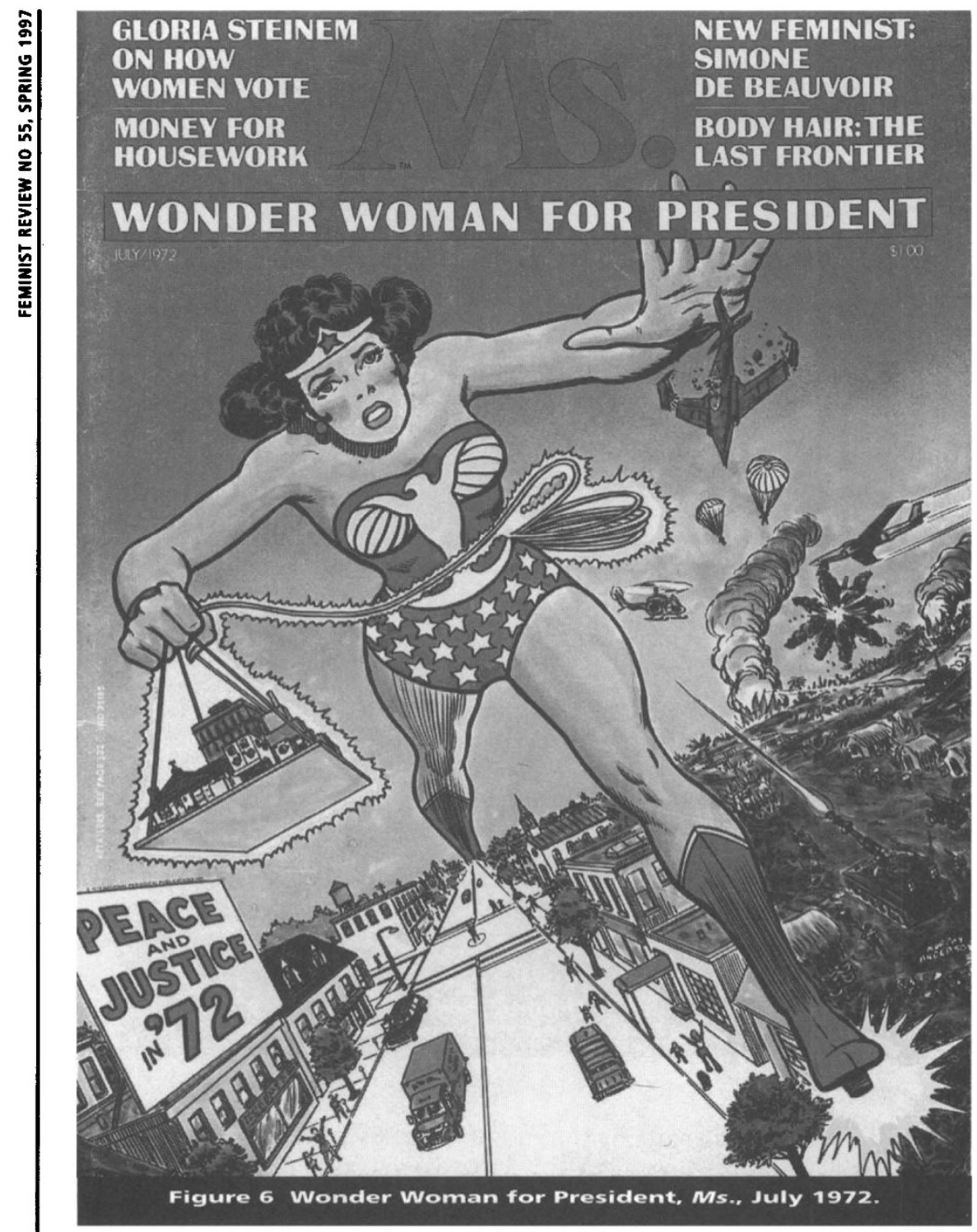

In their ground-breaking 1973 pamphlet on medicine and politics, feminist academic and activist historians Barbara Ehrenreich and Deirdre English reprinted the Sister Wonder Woman figure seizing the speculum. The context was the chapter on the future, in which the authors emphasized that

[s]elf help is not an alternative to confronting the medical system with the demands for reform of existing institutions. Self help, or more generally, selfknowledge, is critical to that confrontation. Health is an issue which has the potential to cut across class and race lines. ... The growth of feminist 
consciousness gives us the possibility, for the first time, of a truly egalitarian, mass women's health movement.

(Ehrenreich and English, 1973: 84-5)

Ehrenreich and English emphasized that not all women had the same histories or needs in the medical system.

For black women, medical racism often overshadows medical sexism. For poor women of all ethnic groups, the problem of how to get services of any kind often overshadows all qualitative concerns. ... A movement that recognizes our biological similarity but denies the diversity of our priorities cannot be a women's health movement, it can only be some women's health movement.

(Ehrenreich and English, 1973: 86, italics in original)

The speculum was not a reductionist symbolic and material tool that limited the feminist health movement to the politics of 'choice' defined by demands for legal, safe abortion and attention to the new reproductive technologies. Nor was the speculum definitive of an exclusivist, middleclass, white movement. The women's health movement was actively built, and often pioneered, by women of colour and their specific organizations, as well as by mixed and largely white groups that cut across class lines. ${ }^{6}$ That legacy is too often forgotten in the terrible history of racism, classblindness, generational arrogance and fragmentation in American feminism, as well as in other sectors of US progressive politics. However, the fullest meanings of reproductive freedom critical to feminist technoscience politics cannot easily be signified by the gynaecological speculum, nor by the speculum of the computer terminal, no matter how important it remains to control, inhabit and shape those tools, both semiotically and materially. The loose configurations of millionaires and billionaires from Paul Simon's song at the head of this essay still determines the nature of the US health system, including reproductive health, for everybody. The structure and consequences of that complex determination are what we must learn to see if 'choice' is to have a robust meaning. The last verse of Simon's 'The Boy in the Bubble' reminds us that the relentless bursts of 'information' - in transnational and rural jungles - are a long-distance call we cannot ignore.

\section{The Statistics of Freedom Projects}

A speculum does not have to be a literal physical tool for prying open tight orifices; it can be any instrument for rendering a part accessible to observation. So, I will turn to another kind of speculum - statistical analysis coupled with freedom- and justice-oriented policy formation - to find a sharper focus for describing what feminists must mean by reproductive 
freedom, in particular, and technoscientific liberty, in general. In this paper, in relation to the goals of feminist technoscience studies, I have adopted the civil rights rallying cry, 'Keep your eyes on the prize!' I mean my appropriation of this phrase to emphasize that conducting an analysis of reproductive freedom from the point of view of marked groups - groups that do not fit the white, or middle-class, or other 'unmarked' standard is the only way to produce anything like a general statement that can bind us together as a people. Working uncritically from the viewpoint of the 'standard' groups is the best way to come up with a particularly parochial and limited analysis of technoscientific knowledge or policy, which then masquerades as a general account that stands a good chance of reinforcing unequal privilege. However, there is rarely only one kind of standard and one kind of relative marginality operating at the same time. Groups that do not fit one kind of standard can be the unmarked, standard or dominant group in another respect. Also, reproductive freedom is only one piece of what feminist technoscientific liberty must include, for women and men. Feminist technoscience studies are about much more than reproductive and health matters. Feminist technoscience studies are about technoscience in general. But, fundamentally, there is no way to make a general argument outside the never-finished work of articulating the partial worlds of situated knowledges. Feminism is not defined by the baby-making capacity of women's bodies; but working from that capacity, in all of its power-differentiated and culturally polyglot forms, is one critical link in the articulations necessary for forging freedom and knowledge projects inside technoscience.

The Associate Counsel and Director of the Black Women's Employment Program of the NAACP Legal Defense and Educational Fund (LDF), Charlotte Rutherford (1992) provides the needed perspective. A civil rights lawyer, feminist, African-American woman and mother, Rutherford articulates what reproductive freedom must mean and shows how both women's groups and civil rights organizations would have to change their priorities in order to take such freedom into account. Her argument is the fruit of intensive meetings with many African-American women's groups and of internal debate in the LDF in 1989-90 on Black women's reproductive health and the US Supreme Court rulings on abortion restrictions. A group of nationally prominent African-American women active in public policy issues 'maintained that reproductive freedoms are civil rights issues for African American women' (Rutherford, 1992: 257). From that perspective, I maintain, reproductive freedom in general has a much sharper resolution.

Included in the LDF formulation of reproductive freedoms for poor women 
1) access to reproductive health care; 2 ) access to early diagnosis and proper treatment for AIDS, sexually transmitted diseases, and various cancers; 3) access to prenatal care, including drug treatment programs for pregnant and parenting drug abusers; 4) access to appropriate contraceptives; 5) access to infertility services; 6) freedom from coerced or ill-informed consent to sterilization; 7) economic security, which could prevent possible exploitation of the poor with surrogacy contracts; 8) freedom from toxics in the workplace; 9) healthy nutrition and living space; and 10) the right to safe, legal, and affordable abortion services.

(Rutherford, 1992: 257-58)

It seems to me that all the citizens would be better served by such a policy than from an approach to reproductive choice or rights that begins and ends in the well-insured, sonographically monitored, Bell Telephone system-nurtured uterus with its public fetus.

Not all African-American women are poor, and not all poor women are African-American, to put it mildly. And all the categories are discursively constituted and non-innocently deployed, both by those who inhabit them (by choice, coercion, inheritance or chance) and those who do not (by choice, coercion, inheritance or chance). I believe that learning to think about and yearn toward reproductive freedom from the analytical and imaginative standpoint of 'African-American women in poverty' - a ferociously lived discursive category to which I do not have 'personal' access - illuminates the general conditions of such freedom. A standpoint is not an empiricist appeal to or by 'the oppressed', but a cognitive, psychological and political tool for more adequate knowledge judged by the non-essentialist, historically contingent, situated standards of strong objectivity. Such a standpoint is the always fraught but necessary fruit of the practice of oppositional and differential consciousness. A feminist standpoint is a practical technology rooted in yearning, not an abstract philosophical foundation. $^{7}$

Therefore, feminist knowledge is rooted in imaginative connection and hard-won, practical coalition - which is not the same thing as identity, but does demand self-critical situatedness and historical seriousness. Situatedness does not mean parochialism or localism; but it does mean specificity and consequential, if variously mobile, embodiment. Connection and coalition are bound to sometimes painful structures of accountability to each other and to the worldly hope for freedom and justice. ${ }^{8}$ If they are not so bound, connection and coalition disintegrate in orgies of moralism. In the kind of feminist standpoint remembered and put back to work in this essay, much important feminist knowledge must be technically 'impersonal'. Statistics have an important but fraught history in the crafting of 
authoritative, impersonal knowledge in democratic societies. The history of statistics is directly related to the ideals of objectivity and democracy.

In Theodore Porter's terms $(1994,1995)$, statistics is a basic technology for crafting objectivity and stabilizing facts. Objectivity is less about realism than it is about intersubjectivity. The impersonality of statistics is one aspect of the complex intersubjectivity of objectivity; i.e., of the public quality of technoscientific knowledge. Feminists have high stakes in the speculum of statistical knowledge for opening up otherwise invisible, singular experience to reconfigure public, widely lived reality. Credible statistical representation is one aspect of building connection and coalition that has nothing to do with moralistic 'standing in the place of the oppressed' by some act of imperialistic fantasy or with other caricatures of feminist intersubjectivity and feminist standpoint. Demanding the competent staffing and funding of the bureaus that produce reliable statistics, producing statistical representations in our own institutions, and contesting for the interpretation of statistics are indispensable to feminist technoscientific politics. Providing powerful statistical data is essential to effective public representations of what feminist and other progressive freedom and justice projects mean. ${ }^{9}$ Recording, structuring, processing and articulating such data should raise at least as interesting scientific problems as any that have merited a Nobel Prize in economics so far.

Porter argued that 'it is precisely the communicability of numbers and of these rules [for manipulating numbers] that constitutes their claim to objectivity. ... The crucial insight here is to see objectivity as a way of forming ties across wide distances' (1994: 48). Porter believed that this kind of objectivity inheres in specialist communities, which rely on expertise rather than on community and which substitute quantitative representations for trust and face-to-face interactions. He sees such modes of objectivity to be ill-adapted to express moral and ethical arguments (1994: 49). However, I believe that the history of struggle to recraft and stabilize public realities as part of learning to put together general policies from the analytical, imaginative and embodied standpoint of those who inhabit too many zones of unfreedom and yearn toward a more just world shows 'impersonal', quantitative knowledge to be a vital dimension of moral, political and personal reflection and action.

Crafting a politics that refuses the constrictions of both the abortion and new reproductive technology debates, with their inadequate discourse of choice, Charlotte Rutherford explores the requirements for reproductive freedom by means of statistical illustrations of the differential conditions that are experienced by women differently marked by race and class in the 
incomes below the poverty level, compared to $8.1 \%$ of white families and $10.7 \%$ of families of all races'. In 1985 , because of the confluence of medically uninsured women's situations and the fact that 80 per cent of private insurance policies did not include office visits or services for preventive care, 'at least $76 \%$ of all women of reproductive age must pay themselves for preventive, non-surgical reproductive health care'. The maternal mortality rate (the number of deaths of mothers per 100,000 live births) for all African-American women in 1986 was 19.3 compared to 4.7 for white mothers. 'In 1986, African American women were 3.8 times more likely than white women to die from pregnancy-related causes.' 'Blacks were more than twice as likely as whites to have late (third trimester) or no prenatal care ... and the frequency of late or no care among American Indians was at least as high as that for Blacks.'

'In 1991, almost five million working mothers maintained their families alone and $22.3 \%$ of them lived in poverty. ... In 1988, of all poor African American families, $75.6 \%$ were maintained by African American women alone, compared to $44 \%$ of poor white families and $47.8 \%$ of poor Hispanic families.' '[I]n 1987 , only $18 \%$ of the pregnancies to women under age 20 resulted in births that were intended, while $40 \%$ resulted in births that were not intended, and $42 \%$ ended in abortion.' 'Among households headed by individuals between 15 and 24 years of age, the poverty rate is staggering: $65.3 \%$ for young African American families and $28.5 \%$ for young white families.' 'The risk of infertility is one and a half times greater for African Americans [ $23 \%$ of couples] than for whites [ $15 \%$ of coupples].' 'Whites and those with higher incomes are more likely to pursue infertility treatment than are African Americans and the poor. 'About $75 \%$ of low-income women in need of infertility services have not received any services. ... Among all higher income women, $47 \%$ [in need of them] have received no services.' Among physicians who provide infertility services in the US, only $21 \%$ accept Medicaid patients for such care. 'By 1982, only fifteen percent of white women were sterilized, compared to twenty-four percent of African American women, thirty-five percent of Puerto Rican women, and forty-two percent of Native American women. Among Hispanic women living in the Northeast, sterilization rates as high as sixtyfive percent have been reported.' Still in the 1990s, the federal government will pay for sterilization for poor women, but not abortions. The worst sterilization abuses of the recent past have been reduced by consent forms and procedures put in place since the 1970 s, but the conditions leading poor women to 'choose' sterilization more often because other options are worse are not acceptable. Meanwhile, 'in 1985 eighty-two percent of all counties in the United States - home to almost one-third of the women of reproductive age - had no abortion provider.' To say the least, the situation 
has not improved in the 1990s. Restrictions on poor women's access to abortion mean later abortions. 'In 1982, after the ban on federal funding was implemented, $50 \%$ of Medicaid-eligible patients had their abortions after nine weeks of pregnancy, compared with only $37 \%$ of non-Medicaideligible women.' 10

Rutherford also shows that toxins and other hazards in neighborhoods and workplaces differentially damage poor people and people of colour because they get more intensive and long-term exposures. To be a houseworker or janitor, hospital worker, farm worker, dry-cleaning or laundry employee, chicken processor, tobacco worker or fabric mill worker is to experience a life-time of toxic exposure that can damage reproductive cells and fetuses, not to mention adult bodily tissues. Pesticides, heat, noise, dust, mechanical hazards, poor nutrition, inadequate medical care, and high levels of stress lower life expectancies of adults, children and fetuses. Those predominantly female occupations held disproportionately by women of colour are especially dangerous to fetal and maternal health. The only thing that might be even more damaging to freedom and health is unemployment. Is anyone really surprised? 'Who cares?' is the fundamental question for technoscientific liberty and science studies. Toxins are a civil rights issue, a reproductive freedom concern, and a feminist technoscience matter; that is, toxins are a general issue for technoscientific knowledge and freedom projects.

The age of designer fetuses on screen is also the age of sharp disparities in reproductive health, and therefore of sharp disparities in technoscientific liberty. In the 1990s, fetuses are objects of public obsession. It is almost impossible to get through the day near the end of the Second Christian Millennium in the United States without being in communication with the public fetus. As Paul Simon sang, these are the days of marvels, when the ubiquitous camera tracks the way we look to distant galaxies. The fetus hurtling through space at the end of the movie 2001 is not a feminist image; neither is the long-distance touch of Bell Telephone. In alliance with the women meeting with Charlotte Rutherford at the Legal Defense and Educational Fund, both Kelly's First Woman with her finger on the divine keyboard and Sister's Wonder Woman seizing the gynaecological speculum must work to make the general community of women publicly visible as movers and shakers in technoscience. That much, at least, is owed to the people who taught us all to keep our eyes on the prize. 'With my speculum, I am strong! I can fight!' There is still a chance, barely, to build a truly comprehensive feminist technoscience politics. 


\section{The Invisible Fetus}

[T]here are many lives and even more deaths to keep track of, numbering the bones of a people whom the state hardly thinks worth counting at all.

Nancy Scheper-Hughes (1992: 30)

It seems fitting to close this meditation on the virtual speculum with an image that is not there - with the missing representations of fetuses and babies that must trouble anyone yearning for reproductive freedom. In a world replete with images and representations, whom can we not see or grasp, and what are the consequences of such selective blindness? From the point of view of a barely imaginable, desperately needed, transnational, intercultural and resolutely situated feminism - a feminism circulating in networks at least as disseminated, differentiated and resilient as those of flexible capitalisms's New World Order, Inc. - questions about optics are inescapable. How is visibility possible? For whom, by whom, to whom and of whom? What remains invisible, to whom and why? For those peoples who are excluded from the visualizing apparatuses of the disciplinary regimes of modern power-knowledge networks, the averted gaze can be as deadly as the all-seeing panopticon that surveys the subjects of the biopolitical state. Moreover, counting and visualizing are also essential to freedom projects. Not counting and not looking, for example in health and well being, can kill in the New World Order as surely as the avid seminal gaze of state curiosity, for example, in the fixing of the criminal or the addict. Similarly, the assumed naturalness of ways of living and dying can be as intolerable as the monomaniacal construction and production of all the world as technical artifact. By now, we should all know that both naturalization and technicization are equally necessary to the regimes of flexible accumulation.

Because my last image springs from a missing gaze, I have no picture to print, no publishing permission to seek. In the demographers' language, this non-image is of human 'reproductive wastage'; i.e., of the dead babies and fetuses, the missing offspring, who populate the earth's off-screen worlds in unimaginable numbers in the late twentieth century. These are fully 'modern' or 'postmodern' fetuses and babies, brought into invisible existence within the same New World Order that ordains bright lights, genetic gymnastics and cybernetic wonders for the public fetuses of the better-off citizens of planet earth at the end of the Second Christian Millennium. These missing fetuses and babies are not residues from some sad traditional past that can be scrubbed clean by the new brooms of modernity and its sequelae in postmodernity's regimes of flexible accumulation. Quite the contrary, the missing images, and what they represent, are 
precisely contemporary with and embedded in the same networks as the all-too-visible, on-screen fetal data structures. If Anne Kelly's on-line fetus is postmodern, so is the uncounted fetus I am seeking in this essay. And vice versa, if 'we' have never been modern, neither have 'they' (Latour, 1993). I continue to use the flawed, deceptive terms 'modern' and 'postmodern' partly to highlight the narratives about time in which we all still generally work and partly to insist on the dispersed, powerful, practical networks of technoscience that have changed life and death on this planet, but not in the ways most accounts of either progress or declension would have it. 'Modern' and its variants should never be taken at face value. I try to force the words - like all meaning-making tools - to stumble, make a lot of racket, and generally resist naturalization. Temporality takes many shapes in the wormholes of technoscience; but the least believable figures are the divisions of the world and its inhabitants into modern and premodern, progressive and traditional, and similar conventions. The solid geometry of historical time is much more troubling than that.

Of course, images of hungry babies and children, if not fetuses, periodically fill our television screens. It is the mode of presence and absence that changes for differently positioned citizens in technoscientific public reproductive visual culture, more than absolute presence or absence. The visual icons of hungry infants do not perform the same semiotic work as the icons of the highly cultivated, on-screen fetuses favored by Bell Telephone. Here, I want to explore one form of off-screen, out-of-frame positioning for the children of contemporary, expanding, marginalized populations.

Nancy Scheper-Hughes is responsible for my missing visual text, as I follow her through her search in the municipal records offices and favelas or slums of a town in a sugar-plantation region of the Brazilian Nordeste over the last twenty-five years. Besides drastically reducing the complexity of accounts in her book, my sketch adds analogies, renarrativizes, and uses parts of her story in ways she did not. But we are enmeshed together in webs spun by yearning and analysis.

Developing John Berger's image, Scheper-Hughes, an anthropologist, saw herself as a 'clerk or keeper of the records' - listening, watching, and recording those events and entities that the powerful do not want to know about (Scheper-Hughes, 1992: 29). The author was tracking births and deaths that still escaped the net of official national or international statistics late in the twentieth century. Scheper-Hughes pointed out that the statistic for infant mortality was first devised in Britain 1875. The British Registration Act of 1834 required that all deaths be recorded and given a medical cause, thus replacing the 'natural deaths' of children and the aged, at least in the intentions of the reformers. Pediatrics emerged as a medical 
specialty in western medicine in the first decades of the twentieth century. Relative to other discourses critical to the regimes of biopower, child survival, much less fetal and infant survival, has a late pedigree everywhere as a problem requiring statistical documentation and action. Childhood malnutrition was first designated a pediatric disease with names in 1933 in the context of colonial medicine. 'Protein-calorie malnutrition in children (of which there was an epidemic in nineteenth-century England) . . only entered medical nosology when British doctors working in the colonies discovered it as a "tropical" disease' (Scheper-Hughes, 1992: 274-5).

For Scheper-Hughes, recording was a work of recognition and an act of solidarity. She attempted to count, to make statistically visible, the reproductive history, and especially the dead babies, of the poorest women in the Brazilian town. Moreoever, she linked the existence and numbers of those dead babies to precisely the same global/local developments that led their richer sisters, living in the neighborhoods in which many of the impoverished favela women worked as domestics, to seek the latest in prenatal care and reproductive medicine. Under-counted and on-screen: those were the two states of being under examination.

Actually, for the middle- and upper-class Brazilian women in this town, modern scientific birth meant delivery by Cesarean section, rather than the 'new reproductive technologies' favored by their northern sisters. ScheperHughes recounted watching young girls play at giving birth by enacting the imagined surgical scenario. After the successful play-birth, the new 'infant was immediately put on intravenous feedings!' (Scheper-Hughes, 1992: 329). Regional newspapers reported that Cesarean section delivery rates among private maternity patients in northeastern Brazil approach 70 percent.

Caught in a nightmare, I am forced to remember another context in which offspring are counted in the regimes of technoscience. An equation in theoretical population biology has two variable quantities, $r$ and $K$, which can be linked to different reproductive 'strategies' adopted by species in the context of the theory of natural selection (MacArthur, 1962). 'K-selected species' are said to 'invest' tremendous resources in each individual offspring and to have rather few offspring over their lives. Each offspring, then, is a valued 'reproductive investment', in the ordinary but nonetheless stupefying languages of investment-portfolio management in which Darwin's theory has been developed in this century. On the other hand, 'r-selected species' are said to adopt the strategy of spewing as many offspring into the world as possible, with little physiological or biosocial investment in any individual, in the hope that some offspring will survive to reproduce. For biologists, all human beings, with their large and 
expensive fetuses and infants, who take many years to mature to reproductive age, are paradigmatic K-selected organisms. Dandelions or cockroaches, with their abundant offspring, none of whom get many nutritious goodies packed into their embryos or much parental attention during development, are typical r-selected creatures. Low infant mortality is the norm for K-strategists; high infant mortality is the normal state of affairs for r-strategists. As the sociobiological authors Martin Daly and Margo Wilson (1978: 124) put it, the contrast is between 'profligacy or careful nurture'. ${ }^{11}$ The mathematical equation need not carry the ideological interpretation that seems to proliferate so readily in the texts of some sociobiologists; but the interpretation is, so to speak, a natural one. Careful parents with solid family values versus vermin and weeds: that seems to be the gist of the story in Daly and Wilson's reading of an equation. I translate this lesson in evolutionary theory into human reproductive politics in the New World Order: intensely cultivated fetuses, located at the centre of national culture and portrayed as individuals from fertilization on, versus throw-away fetuses and dead babies, located 'down there' and known only as 'angels'.

In the US imperialist imaginary, societies 'down there' relative to the United States, in the warm and sordid regions of the planet, seem to have lots of human beings who act like r-strategists. The colder, more cerebral, less genital climes to the north - if one discounts immigrants of colour and other non-progressive types common in racist imagery - are replete with good K-strategists. The blunt racist imagery of the warm, sordid, genital, fecund and coloured tropics contrasted to the cold, hygienic, cerebral, reproductively conservative and white north is officially disavowed and discredited; but I believe it still haunts US popular and technical discourse on many levels and on many occasions, including elections and periods of white middle-class frenzy about 'welfare mothers'.

Scheper-Hughes estimated that the shantytown women she worked with, or for whom she could get records, had about six more pregnancies than their wealthier townswomen living nearby, but ended up with only one more living child. In her ethnographic account, poorer women, especially in younger cohorts, expressed a preference for fewer children than did more affluent women, not more. These preferences were not realizable in the semiotic and material conditions that the women experienced.

Simultaneously, the supposedly natural craving for a healthy child genetically related to the parents, which is said to drive reproductive heroics in contemporary wealthy nations or parts of town, seems to be a bad joke about $\mathrm{K}$-selection. The fetus - and the child tied into lucrative markets of all kinds 
industries, who have much more money than mothers and fathers, seem to be the major reproductive investors. Meanwhile, literally many hundreds of millions of children experience serious deprivation, including 15 million hungry children in the United States in the mid-1990s. 'In the U.S., 30 million people suffer chronic under-consumption of adequate nutrients. Almost half of the hungry are children . . 76\% of the hungry are people of color' (Allen, 1994: 2). In October, 1994, in race-undifferentiated figures, the US Census Bureau reported that 15 percent of the population, i.e., 39.3 million people, officially lived in poverty in 1993. That year, the federal government defined poverty as a family of four with a total annual income of $\$ 14,800$ or less. The US child-poverty rate is about double that of any other industrialized nation. Thus, the stereotypical rich people's lament that the poor have too many children is an even worse joke about r-selection. There is too much hunger, and hunger of too many types, independently of whether there are too many children of the rich or of the poor.

I strongly believe that there are too many people on earth, not just millions, but billions, too many for long-term survival of ourselves and incomprehensible numbers of other species. That belief in no way softens questions of justice and freedom about who survives and reproduces and how. The individual human beings matter; the communities matter. Counting matters. Further, reducing population growth rates and absolute numbers in every class, race, ethnicity and other category on earth will not necessarily reduce habitat destruction, urban or rural poverty, pollution, hunger, crime, agricultural land devastation, overcrowding, unemployment, or most other evils. Population levels are not causes in such a simple sense. The story of inter-relationship is much more complex, and it is hotly contested. I am convinced that the success of comprehensive freedom and justice projects would do a much better job of alleviating suffering and reducing resource and habitat devastation than population limitation policies in the absence of such commitments. Those statements are also beliefs, ones deeply enmeshed in the fraught worlds of technoscience.

On the one hand, it seems that demographers and population specialists of every stripe do nothing but count human beings. United Nations reports, World Bank studies, national censuses and innumerable reference works are full of data about population and reproduction for every spot on earth. On the other hand, a clerk of the records - working out of the traditions of Catholic liberation theology, socialist feminism, medical anthropology and risk-taking ethnography - was still needed to count missing children in the biopolitical age. In a time of crushing overpopulation, the perverse fact is that there are too few living babies among the poorest residents on earth, too few in a sense that matters to thinking about technoscience studies and reproductive freedom. These missing and dead babies are, of 
course, intrinsic to the on-going production of overpopulation. The surplus death of the children of the poor is closer to a cause of overpopulation than one is likely to find by many other routes of analysis. The 1994 United Nations meetings on population and development in Cairo prominently advanced this proposition. Getting a grip on the motor of this surplus death is a problem of world-historical proportions. Wherever else this problem leads, it should take us to the centre of feminist technoscience studies.

To pursue these claims, let us turn back to Nancy Scheper-Hughes' story. A US white citizen, she first went to the favelas of the Nordeste of Brazil in 1964 as an idealistic 20-year-old public health and community development worker. In those years, she came to know many women of a particular community, and she got involved in community-action programmes for childcare and child health. Between 1982 and 1989, after an absence of fifteen years, Scheper-Hughes returned four times to the same community, this time as an anthropologist, an identity she had earlier disdained. The turbulent political and economic contexts of Brazil throughout those years were never far from the surface. In oral interviews and less formal interactions, Scheper-Hughes listened to the women living in this particular shantytown as they recounted reproductive histories and their meanings. She also haunted the records offices of the municipality and of hospitals, forcing recalcitrant institutions and bureaucrats to disgorge data on births and child deaths. Trying to get a grip on how many of which classes died in a year, she talked with the municipal carpenter, whose main job seemed to be making coffins for the children of the poor. His requisitions for the materials needed to make the boxes for dead 'angels' gave her more numbers for her growing numerical testimony.

Scheper-Hughes' figures covered several years and allowed some sense of the trajectory of infant and child death and of the reproductive histories of women of different generations. Besides combing local, regional and national data sources, Scheper-Hughes talked to pharmacists, grocers, priests and anybody else who could cast some light on her questions about birth, life and death among the very young and very poor. She talked to the better-off citizens and prowled through data on them, getting a grip on their different reproductive experiences. Across the period of her study, laws and practices governing registration of births and deaths changed substantially. There is no illusion of comprehensive data in Scheper-Hughes' accounting, but there is nonetheless an arresting ethnographic picture of infant birth and death in the flexible matrices of the New World Order.

There is nothing particularly modern about high rates of birth and infant and child mortality for our species. The opposite is supposed to be the case. The orthodox story of modernity has it that a demographic transition occurs more or less reliably with modern economic development, such that 
both death rates and birth rates decline, albeit rarely if ever in a neatly coordinated fashion. 'Rates' themselves are a particularly modern sort of discursive object; knowledge about progress is inconceivable, literally, without knowledge of rates of change. Death rates go down first, followed at variously unfortunate intervals by birth rates. But, whatever the fits and starts of different rates for births and deaths, modernity brings in its wake a greatly lowered rate of infant and child death as a fundamental part of the demographic transition to stable populations and low birth rates.

The people among whom Nancy Scheper-Hughes studied, however, experienced quite another sort of demographic transition. Scheper-Hughes called the pattern the 'modernization of child mortality' and the 'routinization of infant death' (1992: 268-339). Scheper-Hughes emphasized the moral, social and emotional relations of mothers and whole communities to the extreme levels of infant death among them. Scheper-Hughes' descriptions and interpretations of parental reactions to child morbidity and mortality in the impoverished Brazilian Nordeste are controversial (e.g., Nations and Rebhun, 1988). But the descriptions of malnutrition and infant mortality are not disputed. Brazil has the eighth largest economy in the world, but about 75 percent of its citizens in the Nordeste are malnourished.

Riveted by the form of modernity and postmodernity Scheper-Hughes describes, I highlight here only a limited part of her story. Over the period of the study, death rates for children over a year old did decline among the very poor, as well as among the better-off. Childhood infectious disease, the traditional 'non-modern' killer of the young, was reduced by immunization. Immunization was not the only way that contemporary allopathic medicine marked the bodies of the extremely poor. In contrast to the infants and children of the rich, the poorest babies also ate a steady diet of strong antibiotics and many other types of medicine. In this context, the marginalized poor might say, 'We have never not been modern.' And death rates among children less than a year old went up; and the killer - drastic under-nourishment, resulting in diarrhea and death from acute dehydration - was highly modern. The modernization of child mortality meant 'the standardization of child death within the first twelve months of life and its containment to the poorest and marginalized social classes' (Scheper-Hughes, 1992: 296). By 1989, in the town Scheper-Hughes studied, 96 percent of all child deaths occurred in the first year of life.

In one sense, the cause of the increase in infant mortality seems obvious and easily remediable - loss of the practice of breast feeding. Restore the practice of breast feeding, which has continued to decrease in each generation in the 'developing world' since about 1960, and the very poor will not see their infants die in such vast numbers. Promote breast feeding, get the 
artificial infant-formula makers to cooperate, teach rehydration therapy, and watch death rates come down. Get poor women to 'choose' breast feeding as their grandmothers once did. These are neither new observations nor obscure solutions, and many people work hard to put them into action.

But Scheper-Hughes argues that the modernization of infant death through starvation and dehydration is intrinsic to the form of development practised in the Third World under the terms set by unleashed national and transnational market forces and structural adjustment policies enforced by world sources of capital. The drastically marginalized populations that teem all over the earth, including in US cities, are the direct result of upto-the-minute (post)modernization policies over the last thirty years, and especially the last fifteen years. In the current, acute, global forms of dependent capitalism, 'marginalized' means anything but 'rare'. For Brazil, Scheper-Hughes narrates the complex patterns of the Economic Miracle, World Bank versions of economic development in the 1980s, practices of structural adjustment, inflation and the resulting falling real wage of the poorest classes. In the years following the military junta in Brazil in 1964, total national wealth increased in the context of the systematic relocation of wealth from the bottom 40 percent of the population to the top 10 percent. Progressively, in the context of mass dislocations and migrations, semi-subsistence peasants have become urban, temporary, day-wage workers in large numbers. Food has become a commodity everywhere and for everyone - including the newborn.

These are the critical determinants of reproductive freedom and unfreedom in the New World Order, with its up-to-the-minute, technoscientifically mediated systems of flexible accumulation. Labour patterns, land use, capital accumulation and current kinds of class reformation might have more to do with the flow of breast milk than whether or not Nestle has adopted policies of corporate responsibility in its Third World infantformula markets. Artificial milk is a reproductive technology, without doubt, as is the human body itself, in all its historical/natural/technical complexity. But agribusiness seed technologies, which come with packages of labour and resource use, or marketing systems for national and international customers are at least as much reproductive technologies as are sonograph machines, Cesarean surgical operations or in vitro fertilization techniques. Those seeds and those marketing patterns are central technoscientific actors, where humans and non-humans of many kinds are mutually enrolled in producing ways of life and death. It is high time that studies of reproductive technologies stop assuming that their central artifacts of interest are to be found only in the biomedical clinic. In several senses, computers in financial centres in Geneva, New York or Brasilia are reproductive technologies that have their bite in the breasts of marginalized women 
and the guts of their babies. It shows in the coffin-maker's invoices; the shelves of local grocery stores, where 'choice' is best studied; and, as we shall see, in (post)modern customs for establishing paternity among the poor.

Why do poor women stop breast feeding in the New World Order? How does technoscientifically mediated capital flow affect paternity-recognition rituals? Why can't 'rational choice' prevail in the favelas of the Nordeste, and perhaps also on the flatlands of the East Bay near San Francisco in California? Scheper-Hughes tells an arresting story about the corporeal economy of breast milk, diarrhea and family formation inside Brazil's economic miracle. With all its local themes and variations, the story travels globally all-too-well. It encapsulates one of the plot structures of postmodern narration - one left out of semiotic textbooks and psychoanalytical theory - in which gender, race, class and nation get up-to-the-minute remakes.

Loosely following Scheper-Hughes' map, let us explore the parameters of breast feeding. In the 1960s the US-sponsored Food for Peace programme introduced large amounts of industrially produced powdered milk into the Third World. A food inscribed with a better technoscientific pedigree and radiating more enlightened purposes would be hard to find. International aid-promoted, packaged baby milk programmes ended in the 1970s; but corporations like Nestle moved in to develop the infant-formula market. Much of this market depends on very small purchases at any one time, not unlike the soft drink industry among the impoverished. Marketing infant formula to the poor is like marketing drugs - small, cheap packages are essential to hooking the customers and developing the mass market. Active organizing emerged against the aggressive, medically inflected marketing of artificial formula to women who could not afford the product over the long haul, nor count on conditions to prepare it hygienically. After a lot of denial and resistance, in response to an international boycott started in 1978, Nestlé finally adopted codes for ethical practice and modified its marketing and advertising patterns. But breast feeding continued to decline, and infant death continued to be modernized. 'Ethics' turns out to have precious little to do with 'choice' in vast areas of technoscience, including the yearning for reproductive freedom.

Four factors converge in this story. First, Scheper-Hughes found that the culture of breast feeding unraveled over a brief period - including both the ability of older women to teach younger women and also poor women's belief in the goodness of what comes from their own bodies, compared to what comes from 'modern' objects, like cans or hypodermic needles. ${ }^{12}$ To emphasize that breast feeding is practice and culture, just as technoscience is practice and culture, is to stress that the body is simultaneously a historical, natural, technical, discursive and material entity. Breast milk is not 
nature to the culture of Nestlé's formula. Both fluids are natural-technical objects, embedded in matrices of practical culture and cultural practice. Women can lose, regain or improve the natural-technical knowledge necessary to breast feeding, just as young elephants can lose the ability to find water in long droughts when most of the older, knowledgeable animals are killed by poaching or by inexpert culling of herds. That comparison is not a naturalization of women, but an insistence on the shared natural-technical matter of living as intelligent mortal creatures on this planet. Within the kind of feminist technoscience studies that makes sense to me, breast-feeding practices, elephant cultural transmission and laboratory and factory knowledge and commodity production are ontologically and epistemologically similar. Historical ways of life and death are at stake in each of the naturaltechnical categories. The differences lie in the all-important specificities.

Second, and related to loss of knowledge about how or whether to breast feed, poor women cannot breast feed babies in the context of the jobs that they can get after the transition from semi-subsistence peasant to urban casual day labourer, including current forms of domestic service. The issue goes way beyond the Brazilian favela that Scheper-Hughes studied. Just as right-wing Californian politicians can and do agitate for withholding medical and educational benefits from the children of the migrant women who take care of these same politician-employers' offspring, modern female employers of other women can and do discourage practices that the wealthy reserve for themselves in the interest of health and family. Breastmilk storage equipment notwithstanding, babies have to be with mothers in order to breast feed consistently. On-the-job breast-feeding facilities, as well as other aspects of affordable and comprehensive childcare, remain pie-in-the-sky labour demands in most places of employment in the US. Discursively, such facilities are costly benefits, not natural rights. It is no wonder that poor women in and out of the 'Third World' have much less chance to 'choose' breast feeding, even if they continue, in spite of everything, to trust their own - disproportionately poisoned - bodies to give better nutrition than modern commodities can. ${ }^{13}$

Third, the shelves in the groceries that served the shantytown citizens were replete with every sort of scientifically formulated milk for infants. Literate or not, the mothers were well versed in all the varieties and their relative merits for babies of different ages and conditions. 'The array of "choices" was quite daunting, and the display of infant-formula powdered milk tins and boxes took up a full aisle of the local supermarket, more than for any other food product' (Scheper-Hughes, 1992: 319). Like the mandatory health warning on cigarette packages in the United States, which disproportionately fill the poorest areas of cities, all the infant milk containers carried required warnings about proper use of the product, consulting a 
physician and refrigeration. Consumer protection is such an illuminating practice in transnational capital's progressive regulatory regimes.

Fourth and last, let us turn to a scenario of family formation, to the kind of scene beloved in psychoanalytic contributions to feminist theory. I am particularly interested here in the material/semiotic rituals that create fathers and in the practices that relocate baby's milk from the breasts disdained by responsible, loving women to the packages - replete with corporate and state warnings - carried into the home by responsible, loving men. I am interested in the metonymy that marks the implantation of the name of the father in the favela and in what such substitutions do to the formation of the 'unconscious' in feminist technoscience studies. I believe this kind of unconscious underlies practices of yearning, oppositional consciousness and situated knowledges. The primal scene in the favela is established and signified by a gift of milk. Father's milk, not semen, is his means of confirming paternity and establishing the legitimacy of his child.

Scheper-Hughes tells that in the conditions of shantytown life, marriage becomes much more informal, consensual and, in my ironic terms, 'postmodern'. 'Shantytown households and families are "made up" through a creative form of bricolage in which we can think of a mother and her children as the stable core and husbands and fathers as detachable, circulating units. ... A husband is a man who provides food for his woman and her children, regardless of whether he is living with them.' The symbolic transaction by which a father 'claims' his child and his woman is to bring the infant's first weeks' supply of Nestogeno, an especially valued Nestlé product in a lovely purple can. A woman who breast feeds is thought of as an abandoned woman, or a woman otherwise unprovided for or sexually disdained by a man. Ideally, the equation is, 'Papa: baby's "milk" (Scheper-Hughes, 1992: 323-5). Through that particular and historical milk, meanings of paternity circulate. In this specific narration of metonymy and substitution, a powerful version of feminist desire is born. The desire is not for a supposed natural mother over and against a violating father, but for a new world order in which women, men and children can be linked in signifying chains that articulate the situated semiotic and material terms of reproductive freedom.

The missing babies of the favela are carried away in diarrhea, a 'sea of froth and brine.... "They die," said one woman going straight to the heart of the matter, "because their bodies turn to water"' (Scheper-Hughes, 1992: 303). Through the signifying flow of commodified milk - which links children and fathers, husbands and wives, First and Third Worlds, centres and margins, capital and bodies, milk and excrement, anthropologist and clerk of the records - we are recirculated back into the turbulent, 
heterogeneous rivers of information that constitute the embryo, fetus and baby as a modern sacrum - or cyborg kinship entity - on the globalized planet earth. The diarrhea of angels mixes with the amniotic fluid of onscreen fetuses. We are accountable for this material and semiotic anastomosis in the body politic and the clinical body of the 'postmodern' human family. The longing to understand and change the fluid dynamics inherent in this kind of anastomosis is what I mean by yearning in feminist technoscience studies.

The signifying chains that make up these kinds of linkages are not, in any simple sense, about cause and effect. The multi-dimensional splices that bind together the New World Order, Inc. cannot be described in linear equations. But these higher-order linkages matter; they are not decorative flourishes. One task of feminist technoscience studies is to construct the analytical languages - to design the speculums - for representing and intervening in our spliced, cyborg worlds. In the Bell Telephone ad, paternity was channelled from the phone through the mother-to-be's touching the sonographic image of the fetus on the video-monitor. In the favela of the Nordeste, paternity was channelled through the gift of scientifically formulated, commodified infant milk. The signifiers of choice for Bell Telephone and for Nestlé parody feminist reproductive freedom and knowledge projects and the dispersed, disseminated, differentiated, 'transnational' yearning that sustains them. In Kelly's cartoon, reproductive choice was interrogated in First Women's authorial touch on the computer keyboard. In Charlotte Rutherford's arguments about reproductive freedom for African-American women, the statistics of inequality bore eloquent testimony to the reproduction of unfreedom. All of these accounts are aspects of the inquiry into reproductive technology in the New World Order. As Wonder Woman put it in 1973, 'With my speculum, I am strong! I can fight!' The right speculum for the job makes visible the data structures that are our bodies.

It was a dry wind

And it swept across the desert

And it curled into the circle of birth

And the dead sand

Falling on the children

The Mothers and the Fathers

And the Automatic Earth

And don't cry, Baby, don't cry.

C 1986 Paul Simon/Paul Simon Music (BMI) 
Donna Haraway is a professor in the History of Consciousness Board at the University of California at Santa Cruz, where she teaches feminist theory, science studies and women's studies. She is the author of Crystals, Fabrics and Fields: Metaphors of Organicism in Twentieth-Century Developmental Biology (1976, New Haven: Yale University Press), Primate Visions: Gender, Race, and Nature in the World of Modern Science (1989, New York and London: Routledge; 1992, London: Verso), Simians, Cyborgs, and Women: The Reinvention of Nature (1991, London: Free Association Books; 1991, New York: Routledge), and a new book, Modest_Witness@Second_Millennium.FemaleMan@_Meets_OncoMouse ${ }^{\mathrm{TM}}$ (1996, New York and London: Routledge).

I would like especially to thank Adele Clarke, Valerie Hartouni, Stefan Helmreich, Lynn Randolph, and the Bay Area Technology and Culture Group for comments on 'The Virtual Speculum'.

1 A revised version of this essay is forthcoming in Donna Haraway, Modest_Witness@Second_Millennium.FemaleMan@_Meets_OncoMouse ${ }^{\mathrm{TM}}$ (1996, New York and London: Routledge).

2 Teresa de Lauretis gave me a copy of an early thirteenth-century 'virtual speculum' called The Creation of Eve, from the Creation Dome in the entrance hall in the Basilica di S. Marco in Venice. In this flat, iconic, narrative painting, God is bending over the sleeping Adam in the Garden of Eden and extracting from his side the rib that will be formed into the first man's wife and companion. This is not the creation scene that has inspired the iconographers of technoscientific advertising, conference brochures and magazine-cover design. For these twentieth-century graphic artists, on the other hand, the touch between God and Adam depicted by Michelangelo has incited orgies of visual quotation. See magazine covers for Omni April 1983, Time 8 November 1993, and Discover August 1992. For fans of Escher in the Artificial Life community, studied ethnographically by Stefan Helmreich (1995), the poster image for the second ALife conference features a visual quotation from The Creation of Adam in the cyberspace mode. This creation scene takes place at night, with a quarter moon shining through a window that is also a screen onto the starry universe. Describing the image, Helmreich (personal communication, 18 May 1995) writes, 'The notion that Man replaces God and renders Woman irrelevant in the new creations of Artificial Life is vividly illustrated . . . in a poster for the second workshop on Artificial Life, in which a white male programmer touches his finger to a keyboard to meet the waiting fingers of a skeletal circuit-based artificial creature (itself somewhat masculine).' The programmer himself is a kind of merman figure; the head and torso is of a human male, but the bottom half is a video display terminal, whose nether end hooks into the eye of the circuitskeletal figure. The Escheresque circular composition, full of arrows and fractal recursive shapes connoting self organization, is a kind of uroborus, eating its own electronic tail in an orgy of self creation. The men who got the conference 
together called themselves the 'self-organizing committee'. The conference was sponsored by the Center for Non-Linear Studies at the Los Alamos National Laboratory in 1990.

3 Gross and Levitt (1994) outrageously caricature the feminist science studies insistence on the contingency of 'reality' and the constructedness of science. It is important that my account of reality as an effect of an interaction, as opposed to a treasure awaiting discovery, not be misunderstood. 'Reality' is certainly not 'made up' in scientific practice; but it is collectively, materially and semiotically constructed - that is, put together, made to cohere, worked up for and by us in some ways and not others. This is not a relativist position, if by relativism one means that the facts and models, including mathematical models, of natural scientific accounts of the world are merely matters of desire, opinion, speculation, fantasy, or any other such 'mental' faculty. Science is a practice, an interaction inside and with worlds. Science is not a doctrine or a set of observer-independent, but still empirically grounded (how?) statements about some ontologically separate nature-not-culture. Minimally, an observing interaction requires historically located human beings; particular apparatuses, which might include devices like the hominid visual-brain system and the instruments of perspective drawing; and a heterogeneous world, in which people and instruments are immersed and which is always pre-structured within material-semiotic fields. 'Observers' are not just people, much less disembodied minds; observers are also non-human entities, sometimes called inscription devices, to which people have materially delegated observation, often precisely to make it 'impersonal'. (As we will see below, statistics can be one of those instruments for making reality impersonal.) 'Impersonal' does not mean 'observer-independent'. Reality is not a 'subjective' construction, but a congealing of ways of interacting that makes the opposition of subjective and objective grossly misleading. These ways of interacting require the dense array of bodies, artifacts, minds, collectives, etc. that make up any rich world. The opposition of 'knowing minds', on one hand, and 'material reality' awaiting description, on the other hand, is a silly set-up. Reality is eminently material and solid; but the effects sedimented out of the technologies of observation/representation are radically contingent in the sense that other semiotic-material-technical processes of observation would (and do) produce quite different lived worlds, including cognitively lived worlds, not just different statements about worlds as observer-independent arrays of objects. I think that is a richer, more adequate, less ideological account than Gross and Levitt's insistence that science is reality driven (1994: 234). Obviously, neither I nor any other science studies person, feminist or otherwise, whom I have ever met or read, mean the 'laws of physics' get suspended if one enters a 'different' culture. That is a laughable notion of both physical laws and cultural, historical difference. It is the position that Gross and Levitt, in deliberate bad faith or else astonishingly deficient reading, ascribe to me and other feminist science studies writers. My argument tries to avoid the silly oppositions of relativism and realism. Rather, I am interested in how an observation-situation produces quite 'objective' worlds, worlds not subject to 'subjective' preference or mere opinion, but worlds that must be lived in consequence in some ways and 
not others. For a theory of 'agential realism', to which my arguments about 'situated knowledges' are closely related, see Barad (1995).

4 This title is in honor of Clarke and Fujimura (1992).

5 Boston Women's Health Book Collective (1976); Nuestros Cuerpos, Nuestras Vidas (1979). The Boston Women's Health Book Collective began putting out Our Bodies, Ourselves in newsprint form in the 1970s as an integral part of activist health struggles. For a bibliography of the early women's health movement and feminist science and medicine studies from the 1970s, see Hubbard, Henifin, and Fried (1982). Despite its extensive concern with instruments and tools, practices in and out of the laboratory, and science-in-the-making, the kind of activist-based material in Hubbard et al.'s bibliography is systematically excluded from professional, academic histories of science and technology studies. See, for example, Knorr-Cetina and Mulkay (1983).

6 See, for example, Committee for Abortion Rights and against Sterilization Abuse (1979); Coalition for the Reproductive Rights of Workers (1980); Black Women's Community Development Foundation (1975); Davis (1981); Smith (1982); White (1990). This literature reflects the dominance of the black-white racial polarity of US society and understates the presence and priorities of other racial-ethnic women in women's health and reproductive politics of that period. See Moraga and Anzaldúa (1981).

7 I am in permanent debt to Nancy Hartsock's (1983) pioneering formulation of non-essentialist feminist standpoint theory. Standpoint theories are not private reservations for different species of human beings, innate knowledge available only to victims, or special pleading. Within feminist theory in Hartsock's lineage, standpoints are cognitive-emotional-political achievements, crafted out of located social-historical-bodily experience - itself always constituted through fraught, non-innocent, material, collective practices - that could make less deluded knowledge for all of us more likely. My arguments in 'Virtual Speculum' also draw from Harding (1992) on strong objectivity as a mode of extended critical examination of knowledge-producing apparatuses and agents; Collins (1991) on the internally heterogeneous and insider/outsider locations that have nurtured Black feminist thought; Star (1991) on viewing standards from the point of view of those who do not fit them but must live within them; Butler (1992) on contingent foundations as achievements and agency as practice rather than attribute; Haraway (1988) on situated knowledges in scientific epistemology and the refusal of the ideological choice between realism and relativism; hooks (1990) on yearning rooted in the historical experience of oppression and inequality, but unimpressed by stances of victimhood - that can bind knowledge and action across difference; Sandoval (forthcoming) on the potential of learning and teaching oppositional consciousness across multiple and intersecting differentiations of race, gender, nationality, sexuality and class; Bhavnani (1993) on feminist objectivity within a polyglot world; and Tsing (1993) on multiple centres and margins and on the stunning complexity and specificity of local-global cross talk and circulations of power and knowledge. That Hartsock, Harding, Hill-Collins, Star, Bhavnani, Tsing, Haraway, Sandoval, hooks and Butler are not supposed to agree about postmodernism, standpoints, science studies or feminist theory is neither my 
problem or theirs. The problem is the needless yet common cost of taxonimizing everyone's positions without regard to the contexts of their development, or of refusing rereading and overlayering in order to make new patterns from previous disputes. I am recontextualizing all of this writing to make a case for how thinking about reproductive freedom should make its practitioners reconfigure how to do technoscience studies in general. Theory and practice develop precisely through such recontextualization. For learning to read the always topographically complex history of feminist theory (and theory projects broadly), see King (1994).

8 Adele Clarke (personal communication, 16 May 1995) reminded me of the history of recent feminist efforts to build reproductive policy from the standpoints of the most vulnerable, e.g., the explicit programme of the Reproductive Rights National Network in the 1970s and 1980s. Clarke recounted the example of the passage of sterilization regulations in California, which applied to all sterilizations, not just those funded by Medicaid. Developed by the Committee for Abortion Rights and against Sterilization Abuse (CARASA), national sterilization regulations applied only to Medicaid recipients. Shepherded by the Committee to Defend Reproductive Rights, the California regulations - the only ones to pass on a state level - were the fruit of difficult coalition-building between middle-class, mostly white women from the National Organization for Women, who were more affected by inaccessible sterilization, and workingclass and non-white women's groups, who were more impacted by abusive sterilization. In the $1990 \mathrm{~s}$, the ordinary situation of multiple and heterogeneous vulnerabilities and capabilities, which imply conflicting policy needs, demands urgent feminist attention in local and global dimensions. The International Reproductive Rights Research Action Group (IRRRAG) is a collaborative, multicountry research project on the meanings of reproductive rights to women in diverse cultural settings. See Petchesky and Weiner (1990). Written by an international group of feminist activists and scholars, the papers in Ginsberg and Rapp (1995) put reproduction at the centre of social theory in general and, through detailed and culturally alert analyses, show how pregnancy, parenting, birth control, population policies, demography and the new reproductive technologies shape and are shaped by differently situated women. Non-reductive feminist reproductive discourse and policy can flourish in this context. For example, Barroso and Corrêa (1995: 292-306) show how the difficult interactions of feminists and researchers around the introduction of Norplant into Brazil resulted ultimately in raised public consciousness, attention to informed consent in Norms of Research on Health approved by the Ministry of Health, and effective local ethics committees. Non-feminist approaches to reproductive technologies still abound everywhere. At the 1994 American Fertility Society's 50th Anniversary Meetings in San Antonio, Texas, a Norplant ad poster prominently featured the words, 'Compliance-free contraceptive'. Thanks to Charis Cussins for a photograph of the poster.

9 For the story of public health statistics intrinsic to freedom projects in the twentieth-century United States, see Elizabeth Fee and Nancy Krieger, 'What's Class Got to Do with Health? A Critique of Biomedical Individualism,' paper presented to the Meeting of the Society for Social Studies of Science, New 
Orleans, 12-16 October, 1994. For a view of a feminist economics think-tank, see the publications of the Washington, D.C., Institute for Women's Policy Research, co-founded by Heidi Hartman, winner of a 1994 MacArthur Fellowship for her work, e.g., Spalter-Roth et al. (1995).

10 In order, figures and quotes are taken from the following pages in Rutherford: 257n8, 258n11, 259n12, 260, 260n15, 264n32, 265n38, 266n45, 267, 268, 268n56, 268n61, 273-4, 280, 280n128.

11 Stefan Helmreich pointed out to me a particularly egregious racial-sexual rendering of $\mathrm{r}$ and $\mathrm{K}$ selection arguments, with people of African descent having more extramarital affairs, Black men having longer penises, Black women having shorter menstrual cycles, and a host of other racist-sexist pseudo-facts leading to the conclusion of different evolutionary strategies among (leaving aside the problem of the biological reality of the categories) White, Black and Oriental populations (Rushton and Bogaert, 1987).

12 'In Brazil the decline in breast-feeding has been precipitous; between 1940 and 1975 the percentage of babies breast-fed for any length of time fell from $96 \%$ to less than $40 \%$. . . . Since that time it has decreased even further' (ScheperHughes, 1992: 317). Breast feeding has also declined in the US. In 1993, only 50 percent of all new mothers initiated breast feeding while in the hospital, and only 19 percent persisted after six months. In the United States, breast feeding is also deeply differentiated by class and race, with the most privileged groups 'choosing' breast feeding the most often, and their less-well-off sisters 'choosing' artificial formula. For example, 70 percent of college-educated mothers breast fed their infants at birth, compared to 43 percent of those with a highschool education and 32 percent of those with an elementary-school education; 23 percent of Black mothers breast fed their babies at birth, compared to 59 percent of White mothers (Blum, 1993: 299). Through its Women, Infants, and Children Program (WIC), the US government purchases about $\$ 1.7$ billion of formula per year for use by poor mothers, covering about 40 percent of all US babies (Baker, 1995: 25). Advertising by formula companies remains a big issue, and it works in conjunction with the absence of childcare and maternal support policies that would make breast feeding feasible for economically disadvantaged people.

13 Lest we lose site of enterpreneurial biotechnology in this essay, genetic engineering is on the way to duplicating human breast milk. The product could be sold to affluent mothers (or bought by public health agencies or health maintenance organizations), whose own milk might not be quite the thing or whose children might not thrive on current artificial milk. Dutch research with cows involves bovine transgenics with milk-specific human genes, so that the animals' secretion mimics the human fluid. See Crouch (1995). I am not opposed to this research as a violation of intimate female experience and cultural categories of nature; but, like Crouch, I am highly skeptical that this research would do as much to improve babies' and mothers' health as similar amounts of R\&D money spent on maternal support policies that increased ordinary breast feeding or on environmental policies that reduced the toxin burden in women's bodies all over the world. 
ALLEN, Patricia (1994) The Human Face of Sustainable Agriculture: Adding People to the Environmental Agenda, Center for Agroecology and Sustainable Food Systems, University of California at Santa Cruz. Sustainability in the Balance Series (Issue Paper No. 4).

AUERBACH, Erich (1953) Mimesis: The Representation of Reality in Western Literature Princeton: Princeton University Press.

BAKER, Linda (1995) 'Message in a bottle' In These Times Vol. 19, No. 20: 24-6. BARAD, Karen (1995) 'Meeting the universe halfway: ambiguities, discontinuities, quantum subjects, and multiple positionings in feminism and physics' in Nelson and Nelson, editors Feminism, Science, and the Philosophy of Science: A Dialogue. Norwell, MA: Kluwer Press.

BARROSO, Carmen and CORRÊA, Sônia (1995) 'Public servants, professionals, and feminists: the politics of contraceptive research in Brazil' in Ginsberg and Rapp (1995).

BHAVNANI, Kum-Kum (1993) 'Tracing the contours: feminist research and feminist objectivity' Women's Studies International Forum Vol. 16, No. 2: 95-104. BLACK WOMEN'S COMMUNITY DEVELOPMENT FOUNDATION (BWCDF) (1975) Mental and Physical Health Problems of Black Women Washington, DC: BWCDF.

BLEECKER, Julian (1995) 'Urban crisis: past, present, and virtual' Socialist Review Vol. 25, No. 1 (Winter).

BLUM, Linda M. (1993) 'Mothers, babies, and breastfeeding in late capitalist America: the shifting contexts of feminist theory' Feminist Studies Vol. 19, No. 2: 291-311.

BOSTON WOMEN'S HEALTH BOOK COLLECTIVE (BWHBC) (1976) Our Bodies, Ourselves: A Book by and for Women 2nd edn New York: Simon \& Schuster.

BOSTON WOMEN'S HEALTH BOOK COLLECTIVE (BWHBC) (1979) Nuestros Cuerpos, Nuestras Vidas Somerville, MA: BWHBC, Inc.

BRAIDOTTI, Rosi (1994) Nomadic Subjects: Embodiment and Subjectivity in Contemporary Feminist Theory New York: Columbia University Press.

BUTLER, Judith (1992) 'Contingent foundations: feminism and the question of postmodernism' in Butler and Scott, editors Feminists Theorize the Political New York: Routledge.

CASPER, Monica (1995a) 'Fetal cyborgs and technomoms on the reproductive frontier: which way to the carnival?' in Gray, Figueroa-Sarriera and Mentor (1995).

CASPER, Monica (1995b) 'The making of the unborn patient: medical work and the politics of reproduction in experimental fetal surgery, 1963-1993'. Ph.D. diss., Graduate Program in Sociology, University of California at San Francisco.

CLARK, Timothy J. (1985) The Painting of Modern Life: Paris in the Art of Manet and his Followers New York: Knopf.

CLARKE, Adele and FUJIMURA, Joan (eds) (1992) The Right Tools for the Job: At Work in Twentieth-Century Life Sciences Princeton: Princeton University 
CLARKE, Adele and Teresa MONTINI (1993) 'The many faces of RU486: tales of situated knowledges and technological contestations' Science, Technology, and Human Values Vol. 18, No. 1: 42-78.

COALITION FOR THE REPRODUCTIVE RIGHTS OF WORKERS (CRROW) (1980) Reproductive Hazards in the Workplace: A Resource Guide Washington, DC: CRROW.

COLLINS, Patricia Hill (1991) Black Feminist Thought: Knowledge, Consciousness, and the Politics of Empowerment New York: Routledge.

COMMITTEE FOR ABORTION RIGHTS AND AGAINST STERILIZATION ABUSE (CARASA) (1979) Women under Attack: Abortion, Sterilization Abuse, and Reproductive Freedom New York: CARASA.

CROUCH, Martha L. (1995) 'Like mother used to make?' The Women's Review of Books Vol. XII, No. 5: 31-2.

CUSSINS, Charis (1996) 'Ontological choreography: agency through objectification in infertility clinics' Social Studies of Science Vol. 26, No. 3.

DALY, Martin and WILSON, Margo (1978) Sex, Evolution, and Behavior: Adaptations for Reproduction North Scituate, MA: Duxbury Press.

DAVIS, Angela (1981) Women, Race and Class New York: Random House.

DOWNEY, Gary and DUMIT, Joseph (eds) (forthcoming) Cyborgs and Citadels: Anthropological Interventions on the Borderlands of Technoscience Seattle: University of Washington Press.

DUDEN, Barbara (1993) Disembodying Women: Perspectives on Pregnancy and the Unborn Cambridge: Harvard University Press.

EDGAR, Joanne (1972) 'Wonder woman revisited' Ms. Vol. 1, No. 1: 52-5.

EHRENREICH, Barbara and ENGLISH, Deirdre (1973) Complaints and Disorders: The Sexual Politics of Sickness Old Westbury, NY: The Feminist Press.

ESCOBAR, Arturo (1994) 'Welcome to cyberia: notes on the anthropology of cyberculture' Current Anthropology Vol. 35, No. 3: 211-31.

FAIRCHILD, Halford (1991) 'Scientific racism: the cloak of objectivity' Journal of Social Issues Vol. 47, No. 3: 101-16.

FEE, Elizabeth and KRIEGER, Nancy (1994) 'What's class got to do with health? A critique of biomedical individualism', paper read at Meeting of the Society for Social Studies of Science, 12-16 October, at New Orleans.

FLOWER, Michael (n.d.) 'Technoscientific liberty', unpublished manuscript, University Honors Program, Portland State University.

FOUCAULT, Michel (1978) The History of Sexuality, translated by Robert Hurley, Vol. 1: An Introduction New York: Pantheon.

FRANKLIN, Sarah (1993a) 'Making representations: the parliamentary debate on the human fertilisation and embryology act' in Edwards, Franklin, Hirsch, Price and Strathern, editors Technologies of Procreation: Kinship in the Age of Assisted Conception Manchester: Manchester University Press.

FRANKLIN, Sarah (1993b) 'Life itself', paper delivered at Centre for Cultural Values, Lancaster University, 9 June.

GASPERINI, Jim (1994) 'The miracle of good multimedia' Wired (February): 198. GINSBERG, Faye and RAPP, Rayna (1991) 'The politics of reproduction' Annual Reviews in Anthropology Vol. 20: 311-43. 
GINSBERG, Faye and RAPP, Rayna (eds) (1995) Conceiving the New World Order: The Global Politics of Reproduction Los Angeles: University of California Press. GINSBERG, Faye D. and TSING, Anna L. (eds) (1990) Uncertain Terms: Negotiating Gender in American Culture Boston: Beacon Press.

GRAY, Chris, FIGUEROA-SARRIERA, Heidi and MENTOR, Steven (eds) (1995) The Cyborg Handbook New York: Routledge.

GROSS, Paul R. and LEVITT, Norman (1994) Higher Superstition: The Academic Left and Its Quarrels with Science Baltimore: Johns Hopkins University Press.

HAMILTON, Joan O'C. (1994) 'Biotech: an industry crowded with players faces an ugly reckoning' Business Week (26 September): 84-90.

HAMPTON, Henry (1986-87) Eyes on the prize: America's civil rights years, 1954-65 Alexandria, VA/Boston, MA: Blackside, Inc., and CPB for WGBH Boston. Television series.

HARAWAY, Donna J. (1988) 'Situated knowledges: the science question in feminism as a site of discourse on the privilege of partial perspective' Feminist Studies Vol. 14, No. 3: 575-99.

HARAWAY, Donna J. (1994) 'Never modern, never been, never ever: some thoughts about never-never land in science studies', paper read at Meeting of the Society for Social Studies of Science, 12-16 October, at New Orleans.

HARDING, Susan (1990) 'If I die before I wake' in Ginsberg and Tsing (1990). HARDING, Sandra (1992) Whose Science? Whose Knowledge? Thinking from Women's Lives Ithaca: Cornell University Press.

HARTOUNI, Valerie (1991) 'Containing women: reproductive discourse in the 1980s' in Penley and Ross, editors Technoculture Minneapolis: University of Minnesota Press.

HARTOUNI, Valerie (1992) 'Fetal exposures: abortion politics and the optics of allusion' Camera Obscura: A Journal of Feminism and Film Theory Vol. 29: 130-49.

HARTOUNI, Valerie (1996) Making Life Make Sense: New Technologies and the Discourses of Reproduction Minneapolis: University of Minnesota Press.

HARTSOCK, Nancy (1983) 'The feminist standpoint: developing the ground for a specifically feminist historical materialism' in Harding and Hintikka, editors Discovering Reality: Feminist Perspectives on Epistemology, Methodology, and Philosophy of Science Dordrecht/Boston: Reidel.

HARVEY, David (1989) The Condition of Postmodernity: An Enquiry into the Origins of Cultural Change Oxford: Basil Blackwell.

HAYS, Denys (1967) The Age of the Renaissance New York: McGraw-Hill.

HELMREICH, Stefan (1995) 'Anthropology inside and outside the looking-glass worlds of artificial life', Ph.D. diss., Department of Anthropology, Stanford University.

hooks, bell (1990) Yearning Boston: Southend Press.

HUBBARD, Ruth, HENIFIN, Mary Sue and FRIED, Barbara (eds) (1982) Biological Woman - The Convenient Myth: A Collection of Feminist Essays and a Comprehensive Bibliography Cambridge: Schenkman.

JANSEN, H. W. and JANSEN, Dora Jane (1963) History of Art Englewood 
KING, Katie (1994) Theory in Its Feminist Travels: Conversations in U.S. Women's Movements Bloomington: Indiana University Press.

KNORR-CETINA, Karin and MULKAY, Michael (eds) (1983) Science Observed: Perspectives on the Social Study of Science Beverly Hills: Sage Publications.

LATOUR, Bruno (1993) We Have Never Been Modern, translated by Porter Cambridge: Harvard University Press.

LORDE, Audre (1984) 'The master's tools will never dismantle the master's house' in Lorde, Sister Outsider: Essays and Speeches Trumansburg, NY: Crossing Press. MACARTHUR, R. H. (1962) 'Some generalized theorems of natural selection' Proceedings of the National Academy of Sciences Vol. 48: 1893-7.

MORAGA, Cherríe and ANZALDÚA, Gloria (eds) (1981) This Bridge Called My Back: Writings by Radical Women of Color Watertown, MA: Persephone Press.

NATIONS, Marilyn K. and REBHUN, L. A. (1988) 'Angels with wet wings won't fly: maternal sentiment in Brazil and the image of neglect' Culture, Medicine and Psychiatry Vol. 12: 141-200.

NEAD, Lynda (1992) The Female Nude: Art, Obscenity and Sexuality New York: Routledge.

NILSSON, Lennart (1977) A Child Is Born New York: Dell.

NILSSON, Lennart (1987) The Body Victorious: The Illustrated Story of our Immune System and Other Defenses of the Human Body New York: Delacourt.

NILSSON, Lennart and HAMBERGER, Lars (1994) A Child Is Born Philips. CD-I. PETCHESKY, Rosalind Pollock (1987) 'Fetal images: the power of visual culture in the politics of reproduction' Feminist Studies Vol. 13, No. 2: 263-92.

PETCHESKY, Rosalind Pollack and WEINER, Jennifer (1990) Global Feminist Perspectives on Reproductive Rights and Reproductive Health New York: Hunter College/Reproductive Rights Education Project.

PICKERING, Andrew (ed.) (1992) Science as Practice and Culture Chicago: University of Chicago Press.

PORTER, Theodore M. (1994) 'Objectivity as standardization: the rhetoric of impersonality in measurement, statistics, and cost-benefit analysis' in McGill, editor Rethinking Objectivity Durham: Duke University Press.

PORTER, Theodore M. (1995) Trust in Numbers: The Pursuit of Objectivity in Science and Public Life Princeton: Princeton University Press.

RANDOLPH, Lynn (1993) 'The Ilusas (deluded women): representations of women who are out of bounds', paper delivered at The Bunting Institute, 30 November.

RAPP, Rayna (1994) 'Refusing prenatal diagnostic technology: the uneven meanings of bioscience in a multicultural world', paper read at Society for Social Studies of Science, 12-16 October, at New Orleans.

RAPP, Rayna (forthcoming) 'Real time fetus: the role of the sonogram in the age of monitored reproduction' in Downey and Dumit, editors.

RUSHTON, J. Philippe and BOGAERT, Anthony F. (1987) 'Race differences in sexual behavior: testing an evolutionary hypothesis' Journal of Research in Personality Vol. 21: 529-51.

RUTHERFORD, Charlotte (1992) 'Reproductive freedoms and African American women' Yale Journal of Law and Feminism Vol. 4, No. 2: 255-90. 
SANDOVAL, Chéla (forthcoming) Oppositional Consciousness in the Postmodern World Minneapolis: University of Minnesota Press.

SCHEPER-HUGHES, Nancy (1992) Death without Weeping: The Violence of Everyday Life in Brazil Berkeley/Los Angeles: University of California Press.

SIMON, Paul (1986) 'The boy in the bubble' Warner Brothers Records, Inc. Song, from the album Graceland.

SMITH, Beverly (1982) 'Black women's health: notes for a course' in Hubbard, Henifin and Fried, editors.

SPALTER-ROTH, Roberta, BURR, Beverly, HARTMAN, Heidi and SHAW, Lois (1995) Welfare That Works: The Working Life of AFDC Recipients Washington, DC: Institute for Women's Policy Research.

STABEL, Ingse (1992) 'Den norske politiske debatten om bioteknologi' Nytt om Kvinneforskning Vol. 3: 43-8.

STABILE, Carol A. (1992) 'Shooting the mother: fetal photography and the politics of disappearance' Camera Obscura: A Journal of Feminism and Film Theory Vol. 28: 178-205.

STAR, Susan Leigh (1991) 'Power, technology and the phenomenology of conventions: on being allergic to onions' in Law, editor A Sociology of Monsters: Power, Technology and the Modern World Oxford: Basil Blackwell.

TREICHLER, Paula and CARTWRIGHT, Lisa (1992) 'Imaging technologies, inscribing science' Camera Obscura: A Journal of Feminism and Film Theory Nos 28 and 29.

TSING, Anna Lowenhaupt (1993) In the Realm of the Diamond Queen: Marginality in an Out-of-the-Way Place Princeton: Princeton University Press.

WHITE, Evelyn (ed.) (1990) The Black Women's Health Book Seattle: Seal Press. 